\title{
Ground thermal and geomechanical conditions in a permafrost-affected high-latitude rock avalanche site (Polvartinden, northern Norway)
}

\author{
Regula Frauenfelder ${ }^{1}$, Ketil Isaksen ${ }^{2}$, Matthew J. Lato ${ }^{3, a}$, and Jeannette Noetzli ${ }^{4, b}$ \\ ${ }^{1}$ Norwegian Geotechnical Institute NGI, Oslo, 0806 Norway \\ ${ }^{2}$ The Norwegian Meteorological Institute, Oslo, 0313, Norway \\ ${ }^{3}$ BGC Engineering Inc., Ottawa ON, Canada \\ ${ }^{4}$ WSL-Institute for Snow and Avalanche Research SLF, Davos, 7260, Switzerland \\ ${ }^{\text {a}}$ Formerly at: Norwegian Geotechnical Institute NGI, Oslo, 0806 Norway \\ ${ }^{\mathrm{b}}$ Formerly at: University of Zurich, Zurich, 8057, Switzerland
}

Correspondence: Regula Frauenfelder (rf@ngi.no)

Received: 29 September 2016 - Discussion started: 15 November 2016

Revised: 8 February 2018 - Accepted: 5 March 2018 - Published: 27 April 2018

\begin{abstract}
On 26 June 2008, a rock avalanche detached in the northeast facing slope of Polvartinden, a high-alpine mountain in Signaldalen, northern Norway. Here, we report on the observed and modelled past and present near-surface temperature regime close to the failure zone, as well as on a subsequent simulation of the subsurface temperature regime, and on initial geomechanical mapping based on laser scanning. The volume of the rock avalanche was estimated to be approximately $500000 \mathrm{~m}^{3}$. The depth to the actual failure surface was found to range from $40 \mathrm{~m}$ at the back of the failure zone to $0 \mathrm{~m}$ at its toe. Visible in situ ice was observed in the failure zone just after the rock avalanche. Between September 2009 and August 2013, ground surface temperatures were measured with miniature temperature data loggers at 14 different localities, close to the original failure zone along the northern ridge of Polvartinden and on the valley floor. The results from these measurements and from a basic three-dimensional heat conduction model suggest that the lower altitudinal limit of permafrost at present is at 600$650 \mathrm{~m}$ a.s.1., which corresponds to the upper limit of the failure zone. A coupling of our in situ data with regional climate data since 1958 suggests a general gradual warming and that the period with highest mean near surface temperatures on record ended four months before the Signaldalen rock avalanche detached. A comparison with a transient permafrost model run at $10 \mathrm{~m}$ depth, representative for areas where snow accumulates, strengthen these findings, which
\end{abstract}

are also in congruence with measurements in nearby permafrost boreholes. It is likely that permafrost in and near the failure zone is presently subject to degradation. This degradation, in combination with the extreme warm year antecedent to the rock failure, is seen to have played an important role in the detaching of the Signaldalen rock avalanche.

\section{Introduction}

In the morning of 26 June 2008, a rock avalanche (cf. Hungr et al., 2014 for nomenclature) detached from the northeast facing slope of Polvartinden (see Fig. 1 and Sect. 2 for site description). The rock avalanche endangered two farms and several recreation cabins, and it destroyed a considerable amount of livestock pastures. A few hours after the event, the first reconnaissance work was carried out, including failure zone assessment by means of visual inspection from a helicopter. In situ ice was observed in the failure zone at different depths during this visual inspection (ca. $20-30 \mathrm{~m}$ below the pre-failure surface and, thus, clearly below the seasonal frost depth; Fig. 2), i.e. clearly indicating permafrost. This observation, together with the absence of typical pre-failure events (such as seismic activity, intensive rainfall, or snow melt) that could have triggered the rock avalanche, led to the hypothesis that warming or degrading of permafrost could have played 

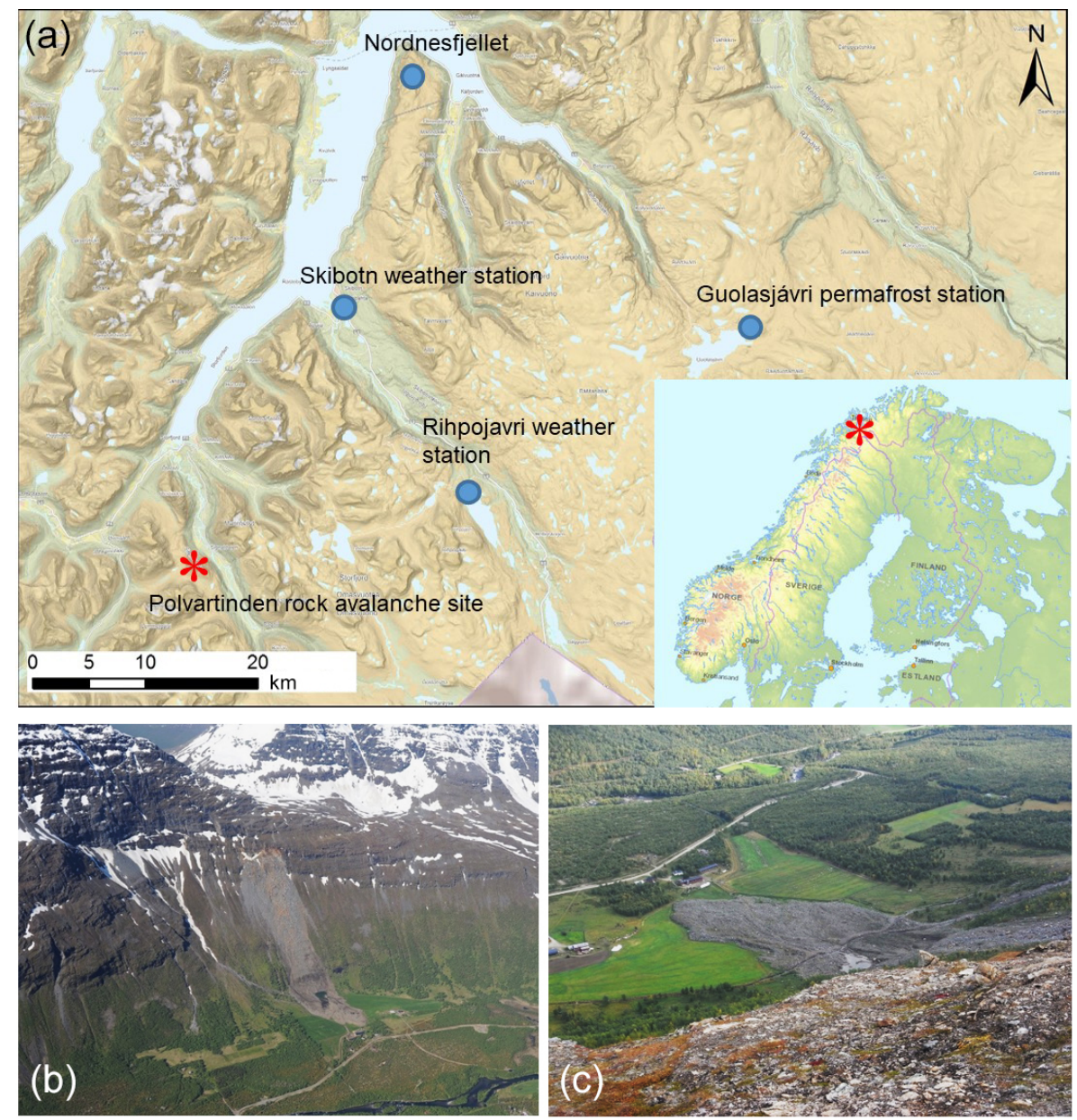

Figure 1. (a) Key map showing the location of the Polvartinden rock avalanche site (red asterisk), the two weather stations, and the permafrost station used in this study, as well as the location of the Nordnesfjellet borehole site referred to in the text (all marked with blue dots). (Map source: Copyright of Norwegian Mapping Authority/Statens kartverk); (b) Signaldalen rock avalanche as seen from helicopter on 28 July 2009 (Photograph by courtesy of Gunnar Kristiansen, NVE); (c) runout area of the Signaldalen rock avalanche in September 2011 (Photograph courtesy of Gunilla Kaiser).

a role in the timing and the magnitude of the event. A year after the event, a temporary temperature monitoring network was put in place and repeated surveying of the failure zone and the adjacent slopes by means of terrestrial laser scanning was initialized.

Scientists have become increasingly aware that atmospheric warming has an impact on the stability of mountain permafrost (e.g. Arenson and Jakob, 2017; Haeberli et al., 2010; Harris et al., 2009; Huggel et al., 2010; Jin et al., 2000; Marchenko et al., 2007; Stoffel and Huggel, 2017). It seems that mountain systems are especially sensitive to a changing climate, due to feedback effects in connection with snow cover, albedo, and heat budgets, which amplify the alterations caused by climate change (Gobiet et al., 2014; Vavrus, 2007; Wang et al., 2014). Several studies from the European Alps show that temperatures have increased twice as much as the global average since around 1900 (e.g. Böhm et al., 2001; Auer et al., 2007). There is also increasing evidence that a link exists between rockfall magnitude and frequency, and timing and depth of permafrost degradation, the latter ranging from seasonal increase of active-layer depths to long-term, deep-seated warming of the permafrost body as a response to atmospheric temperature rise (e.g. Gruber and Haeberli, 2007; Ravanel and Deline, 2010; Stoffel et al., 2014). Fischer et al. (2012) collected published material on large rockslide and rock avalanche events (volumes between $10^{5}$ and $10^{7} \mathrm{~m}^{3}$ ), as well as on more frequent small-volume rockfall events. Their study concludes that such events occur worldwide in periglacial environments, and that many of the reviewed studies suggest that the reported events may be related to ongoing and/or past changes in permafrost and glacierization. Corresponding events have, for example, been documented for the European Alps (e.g. Barla et al., 2000; Crosta et al., 2004; Gruber et al., 2004a; Cola, 2005; De- 


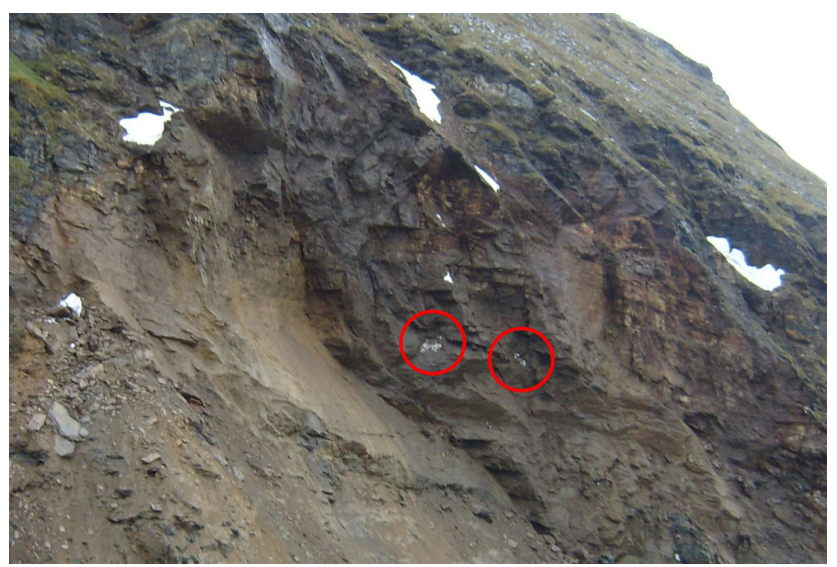

Figure 2. Visible in situ ice (encircled areas) observed in the rock avalanche failure zone on 26 June 2008. The photograph was taken a few hours after the event (Photograph by courtesy of Kjetil Brattlien, NGI).

line et al., 2011; Oppikofer et al., 2008; Ravanel and Deline, 2010; Phillips et al., 2016), Canada and Alaska (e.g. Evans and Clague, 1994; Geertsema et al., 2006), the Caucasus (e.g. Haeberli et al., 2004), and for New Zealand (e.g. Allen et al., 2011). The evidence of permafrost-related destabilisation is not only derived from observation (through abductive inference), where the relative importance of permafrost degradation remains difficult to prove, but also supported by (deductive) mechanical studies that explain the underlying physics and processes of destabilisation (cf., e.g. Arenson and Springman, 2005; Arenson et al., 2007; Davies et al., 2001; Dräbing et al., 2013; Dwivedi et al., 1998, 2000; Günzel, 2008; Inada and Yokota, 1984; Jia et al., 2016, 2017; Krautblatter et al., 2013; Mellor, 1973).

In mainland Norway (i.e. excluding Svalbard), permafrost occurs mainly in the central mountain chains and in higher latitude areas, such as the counties of Troms and Finnmark (Gisnås et al., 2017). Early studies, e.g. King (1986), Ødegård et al. (1996), Etzelmüller et al. (2003) and Heggem et al. (2005) have shown that permafrost is discontinuous in the higher mountains of central southern and eastern Norway. More recent studies show that permafrost temperatures generally are between -3 and $0^{\circ} \mathrm{C}$ in the higher mountains of northern Norway (e.g. Farbrot et al., 2011) and that warming and degradation of the permafrost is ongoing both at sites with cold permafrost, with marginal permafrost and with deep seasonal frost (Isaksen et al., 2011).

In western and northern Norway, fjords and valleys are confined by steep mountain slopes, which leads to a limitation of areas where human infrastructure can be built; this often results in the infrastructure being located close to the steep mountainsides. Large-scale rock-slope failures therefore pose a significant geohazard in these areas (Blikra et al., 2006), both due to the potential risk of a direct hit in case of a slope failure, but also due to the potential risk of rock slope failures generating tsunamis in the fjords or damming up rivers in the valley floors, with the subsequent risk of major flooding. Mass movements generated from such slopes and their secondary effects have caused hundreds of fatalities during the last 500 years in Norway. Understanding of the destabilization processes and the classification of their risk has thus become a major field of research (Hermanns et al., 2012, 2013, 2016).

Due to the increased awareness of the potential role of permafrost degradation to the risk of slope failures, a permafrost and climate monitoring programme was initiated in 2002, along climate and altitudinal transects in Troms and Finnmark, the two northernmost counties of mainland Norway (Isaksen et al., 2008; Farbrot et al., 2013). In 2003, a permafrost programme was launched in the Gaissane Mountains in the northernmost county of Finnmark (Farbrot et al., 2008). In the mountains of Troms two 30-32 $\mathrm{m}$ deep boreholes were drilled in 2004 at altitudes of 786-850 m a.s.l. (Farbrot et al., 2013). These studies found permafrost to be warm, but widespread in alpine areas in northern Norway. The existing monitoring network in northern Norway was more extensively instrumented and extended with new boreholes in Troms and Finnmark during the third International Polar Year 2007-2009 (cf., Christiansen et al., 2010; Juliussen et al., 2010). Through extensive analyses of these borehole data, Farbrot et al. (2013) found that the combined effects of snow depth and vegetation cover are the two most critical factors for the existence of permafrost in northern Norway. They also concluded that the depth of seasonal frost or active layer in areas underlain by exposed bedrock was more than $10 \mathrm{~m}$ at several sites and was amongst the deepest reported in the international literature, and that the altitude of the lower limit of permafrost has probably increased around 200-300 m since the end of the Little Ice Age (LIA) (Farbrot et al., 2013). This was supported in a recent study by Myhra et al. (2015) who modelled permafrost distribution and longterm thermal changes in, among others, a steep rock wall at Revdalsfjellet. Revdalsfjellet is situated close to the unstable and extensively monitored Nordnesfjellet - where permafrost has been suggested as one of the mechanisms controlling the ongoing slope failure (Blikra and Christiansen, 2014; Blikra et al., 2015) - and $25 \mathrm{~km}$ from our Signaldalen site. Myhra et al. (2015) modelled a bedrock warming at 20 and $50 \mathrm{~m}$ depth of about 1.0 and $0.5^{\circ} \mathrm{C}$, respectively, from the end of the LIA and using a present lower limit of permafrost of about $650 \mathrm{~m}$ a.s.l. at Revdalsfjellet. A new Nordic permafrost map based on modelled results confirm ongoing degradation of mountain permafrost in the fjord areas in Troms (Gisnås et al., 2017).

In this paper, we present analyses of a four-year temperature data series from near-surface temperature loggers, subsequent modelling of the temperature regime, and basic geomechanical mapping in Signaldalen, northern Norway, at a high-latitude, high-relief rock avalanche site. The main objective of our study is to increase our understanding of the 
permafrost temperature regime at the site and what role the ground temperatures might have played in the release of the rock avalanche. Further, our results contribute to the understanding of the influence of solar radiation on near surface temperatures in different aspects of steep mountain walls at high latitudes.

\section{Site description}

Polvartinden is a $1275 \mathrm{~m}$ high mountain located in the Signaldalen valley, Troms county, northern Norway (at $\left.69^{\circ} 10^{\prime} 18^{\prime \prime} \mathrm{N}, 19^{\circ} 57^{\prime} 47^{\prime \prime} \mathrm{E}\right)$. The failure zone is located approximately $600 \mathrm{~m}$ above the valley bottom, on the western side (facing north-east) of the valley. The larger area around the failure zone, outside the steepest slope, is characterized by a combination of small vertical rock outcrops and undulating slopes with an established soil cover. Figure 1 shows the location of the Polvartinden rock avalanche site, the two weather stations, and the permafrost station used in this study, as well as the location of the Nordnesfjellet borehole site referred to in the text.

\subsection{Bedrock geology and tectonics}

The Signaldalen area is mostly composed of metasedimentary rocks of the Caledonian Nappe sequence. The latter were placed upon the Precambrian basement in the Early- to MidPalaeozoic time period as a result of the closure of the Iapetus Ocean. Series of flat-lying north-east-south-west striking nappes were pushed upon the Precambrian basement from the north-east during the Caledonian orogeny (Andresen, 1988; Fossen et al., 2007). The different nappes represent different degrees of displacement and metamorphism, with an upward increase in the degree of metamorphism (Roberts and Gee, 1985; Roberts, 2002; Fossen et al., 2007). An era of extensional tectonics followed the Caledonian orogeny and caused the opening of the Atlantic Ocean and development of the Norwegian passive continental margin (Fossen et al., 2007). Several phases of extension forces have resulted in different fault systems; those can be tracked both onshore and offshore (e.g. Bergh et al., 2007; Hansen, 2009). The western side of the Signaldalen valley, i.e. the side where the rock avalanche released, is characterized by large-scale faulting. Regionally, the layers are striking towards the south, and dipping to the north-west. Locally, around the failure area, the rock boundaries lie almost horizontally (Fig. 1b). In addition, there is a near surface-parallel surface where the failure has occurred. According to the $1: 250000$ geological map of the area (http://geo.ngu.no/kart/berggrunn_mobil/) the failure zone is located within a layer of calceous mica schists and calceous silica gneiss.

\subsection{Glaciation and deglaciation history, postglacial uplift}

The present regional morphology, topographic gradient and landscape, together with the ongoing isostatic uplift, are the result of hundreds of million years of geological evolution. During each new glaciation, glacier-products from former glaciations, as well as post-glacial deposits, were modified or totally removed. The last glaciation, the Weichselian (ca. 118000 to 11500 years ago) is therefore particularly important for the morphology of the study area today. The Last Glacial Maximum (LGM) was reached between ca. 25000 to 18000 years ago (Sveian, 2004; Nesje, 2012). During this time, the ice sheet covered almost all of Scandinavia, and reached the shelf edge where it deposited great amounts of sediments (Vorren and Mangerud, 2007), with the larger fjords serving as main drainage pathways (Sveian and Corner, 2004).

Climatic change at the end of the LGM caused the retreat of the ice shield from the shelf edge. During the first period of the glacial retreat, the ice shield withdrew from the shelf edge to the outer coast areas, and later into the fjords (Vorren and Mangerud, 2007). Postglacial uplift in Fennoscandia is a direct response to the deglaciation after the LGM. The landscape exposed after the last glaciation was in an unstable condition, and thus particularly exposed to modification at high denudation rates. Glacially steepened rock walls and slopes were sites of mass reworking (Ballantyne, 2002). Recent studies reveal a rapid rock slope instability response to the initial local decay of the Scandinavian ice sheet followed by a lower and constant frequency following the climate optimum in the Holocene (e.g. Hermanns et al., 2017; Schleier et al., 2017). In northern Norway, two periods of major seismicity (earthquakes on the order of $\geq 6.0 M_{\mathrm{w}}$ ) have been suggested, due to the stresses following the postglacial uplift: one before $11000{ }^{14} \mathrm{C}$ years $\mathrm{BP}$ and one between 10000 and 9500 years BP. These seismic events probably explain the high number of rock avalanches in the region (Dehls et al., 2000).

\section{Methods}

\subsection{Geomechanical mapping}

In order to map the thickness and the geometrical characteristics of the failure zone, the release area was repeatedly surveyed by terrestrial laser scanning (TLS). This allowed also for monitoring of eventual continued or new movement in the slope. In the autumns of 2010, 2011, and 2013, the failure zone of the rock avalanche was imaged with an HD Optech ILRIS terrestrial laser scanner (Optech Incorporated, Canada). In addition, the failure zone and its surroundings were imaged with a Giga-Pan camera in autumn 2013. The purpose of the laser scanning data collection was to develop a 

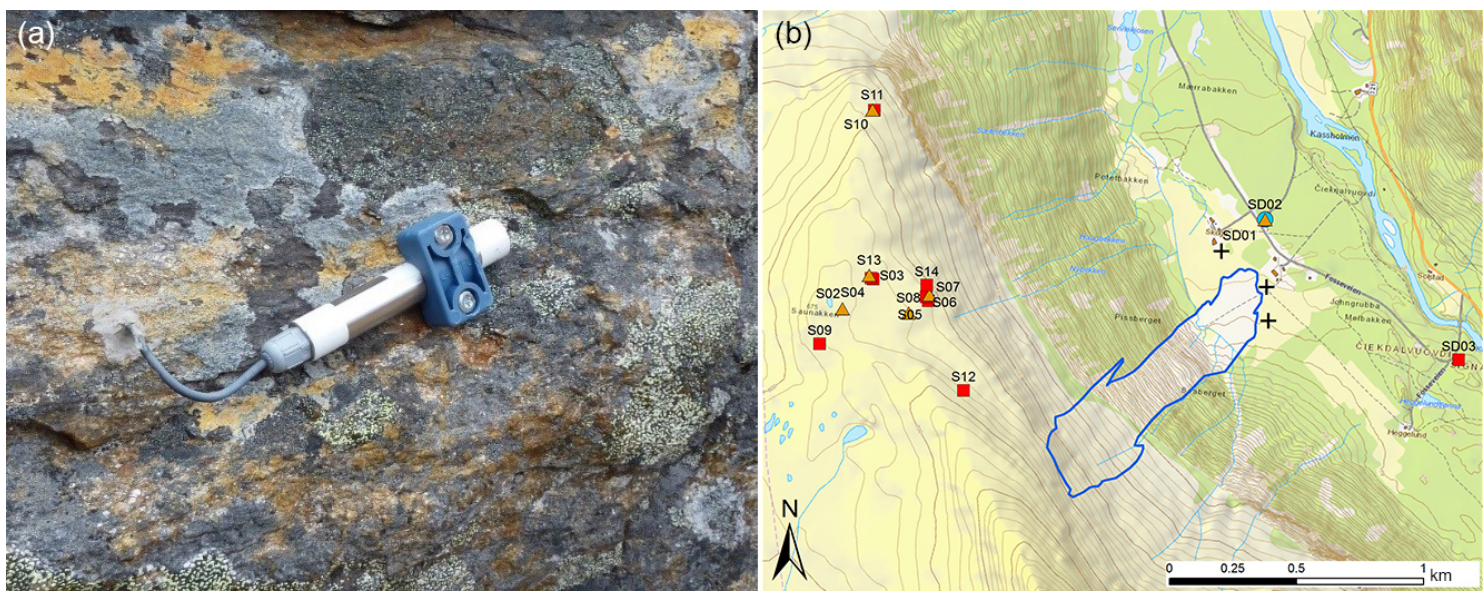

Figure 3. (a) Typical logger installation setup for the M-Log5W loggers. (b) Map showing temperature measurement locations in vertical rock faces (red squares), within soil material (yellow triangles), and within a stone cairn (one blue circle in the valley bottom). The three black crosses mark the laser scanning locations. Rock avalanche outline in blue. Map source: Copyright of Norwegian Mapping Authority/Statens kartverk.

digital terrain model to enable the quantification of the extent and volume of the failure zone. The data needed to be of significant resolution to enable the detection of temporal surface changes, and to identify zones with differential movement.

The altitude of the failure zone in combination with the slope of the mountain side resulted in the failure zone being located approximately $800-1100 \mathrm{~m}$ away from the nearest possible scanning locations. To produce a 3-D terrain model with a minimal amount of occlusion, data was collected from three independent locations (identified in Fig. 3). Each location was selected because it provided an excellent line-of-sight to the failure zone and reduced the bias in extraction of discontinuity orientations in accordance with Lato et al. (2010). Data was collected at varying resolutions. Low-resolution data was collected to enable the visualization of a large area of the mountainside. Higher resolution data was collected at specific zones near the failure zone and its surrounding areas to enable a geomechanical interpretation. This data has a resolution of approximately $0.20 \mathrm{~m}$ point spacing (or $25 \mathrm{pts} \mathrm{m}^{-2}$ ). Given the scanning distance, this was the highest reasonable resolution of data we could collect at the time with the available lidar technology. Occluded zones on the rock face were limited to surfaces parallel to the scanner orientation and regions with ice cover. The size of these regions varied from 1 to $10 \mathrm{~m}^{2}$. These regions do not negatively impact the geomechanical interpretation since they represent less than $1 \%$ of the total model area. The orientation of structural discontinuities were manually identified and orientation vectors were converted to dip and dip direction measurements (Lato et al., 2012). The structural measurements were extracted from a 3-D surface mesh that was generated from the overlapping point cloud datasets.

Calculating the volume of the failed mass was completed based on interpolation and estimation. Since a sufficiently high resolution 3-D image of the area before the failure does not exist, an interpolated surface had to be used to estimate the volume. The extent of the pre-failure surface was delineated based on the visual contrast between the appearance of the pre-failure and post-failure rock mass in the photographs and based on intensity values in the lidar data set. The volume estimation was completed using both PolyWorks and ArcGIS software packages. The volume of the 2008 rock avalanche was computed using the 2012 TLS data by delineating a prefailure surface based on adjacent slope topography bounding the scarp. The differential volume was computed using standard 3-dimensional techniques, as presented, e.g. by Lato et al. (2014).

\subsection{Temperature measurements and ground temperature modelling}

In situ measurements of ground surface temperatures and subsequent ground temperature modelling was employed to get insight into the past- and present temperature regime at and near Polvartinden peak. Due to the two different types of small-scale topography found around the failure zone (see Sect. 2 for site description) snow cover and snow depth varies considerably. Consequently, temperature loggers were installed in both types of terrain, i.e. in vertical rock outcrops (rock surface temperature, RST) and within soil material on the more gentle slopes (soil surface temperature, SST). To obtain a robust estimate of how past and present ground temperatures had evolved prior to the failure, i.e. in the longand in the short-term, two different approaches were used: Firstly, the RST in selected rock outcrops were linked to long-term changes in regional air temperature by comparing their statistical relation with temperature data from the official weather stations Skibotn (5 m a.s.l.) and Ripojavri (502 $\mathrm{m}$ a.s.l.); for locations see Fig. 1. We found that the 
linkage between those two datasets was strongest for rock outcrops with little or no snow, i.e. with a fairly direct link to the atmospheric conditions. Therefore, it was desirable to look further into the temperature development in the ground in more gentle slope areas close to the release area with a more established snow and soil cover. To this aim, the CryoGrid2 model (cf. Westermann et al., 2013) was used. Since Polvartinden is an alpine peak, with three-dimensional effects that affect the ground temperature field inside the mountain, the lower permafrost limit will vary according to different aspects. In order to better understand the present subsurface temperature field of Polvartinden and to get a better idea of how the lower permafrost limit is located with respect to the release area of the rock avalanche, a stationary three-dimensional transient heat conduction model (cf. Noetzli et al., 2007a, b) was used in addition. It was natural to install loggers in different compass directions to study the differences in surface temperature as a result of aspect dependency. As input data for the analyses of aspect dependency robust estimates of air temperature were needed at each rock wall logger locality to enable the calculation of the temperature difference $(\Delta T)$ between calculated air temperature and measured rock face temperatures (surface offset).

\subsubsection{Ground surface and air-temperature measurements}

Ground surface temperatures were measured at 14 locations employing miniature temperature data loggers of three different types: M-Log5W loggers (GeoPrecision GmbH, Germany), redesigned UTL-1 loggers (University of Bern and University of Zurich, Switzerland, cf. Gruber et al., 2003), and UTL-3 loggers (GEOTEST and WSL Institute for Snow and Avalanche Research SLF, Switzerland). We followed the installation setup described by Gruber et al. (2003), hence measuring near-surface rock temperatures at $10 \mathrm{~cm}$ depth (Fig. 3a). The absolute accuracy for all three logger types is $\pm 0.1^{\circ} \mathrm{C}$. The resolution of M-Log5W, UTL-3 and UTL-1 is $0.01,0.02$ and $0.27^{\circ} \mathrm{C}$ respectively. The M-Log5W loggers and the UTL-3 loggers were programmed to measure every $30 \mathrm{~min}$, while the UTL-1 loggers (having smaller memory capacities than the other two employed logger types) measured every $2 \mathrm{~h}$. Based on experiences from long-term permafrost monitoring programs in Norway using such loggers (e.g. Isaksen et al., 2011; Gisnås et al., 2017) we claim that the bias on the accuracy of the temperature measurements introduced with the given setups is negligible.

Installation sites for RST were chosen based on the availability of near-vertical rock outcrops, their closeness to the original failure zone and, last but not least, the accessibility of the identified locations. Where possible, a vertical distance of several metres to the flat terrain was chosen. However, this was not possible at all of the sites, which has some implications on the interpretation of the results (cf. Sect. 4). The 14 measurement sites finally chosen are plotted on the map shown in Fig. 3b; they are located along the north-north-west ridge of Polvartinden and in the valley ground.

Measurements were ongoing from September 2009 to $\mathrm{Au}-$ gust 2013 for 10 out of 14 loggers. For R09 and R10 only data for 2009-2011 exists, while R12 and R13 where first installed in 2011, thus yielding data for 2011 to 2013. Nine RST-loggers (type M-Log5W and redesigned UTL-1; identified as R\# loggers in text and figures) were installed in vertical rock faces on rock outcrops and along small cliffs with different aspects, while five SST-loggers (standard UTL1/UTL-3; identified as S\# loggers in text and figures) were placed directly into the soil at ca. $10 \mathrm{~cm}$ depth in order to measure SST. One additional logger was placed in a cairn in the valley floor to monitor air temperature. For several of the analyses presented annual mean values were calculated to identify variations in mean annual rock- and soil surface temperature (MARST and MASST respectively) and mean air temperature (MAAT). This ensures easier comparison between the monitoring sites and makes it easier to identify local maxima and minima as well as trends (cf. Isaksen et al., 2011).

\subsubsection{Ground surface temperature modelling}

\section{Long-term changes in ground temperatures}

To study long-term changes in ground temperatures representative for the same elevation as the failure zone, but for sites with a developed soil cover and where snow accumulates, we used data series from the transient permafrost model CryoGrid2 (CG2; cf. Westermann et al., 2013). The physical basis and operational details of CG2 are documented in Westermann et al. (2013), and only a brief overview over the model properties is given here. CG2 calculates ground temperatures according to Fourier's law of conductive heat transfer in the soil and in the snowpack to determine the evolution of ground temperature over time. Thus, CG2 can deliver the transient response of ground temperatures to a changing climate. In addition to conductive heat transfer, the change of internal energy and temperature in the ground is determined by the latent heat generated/consumed by soil freezing/thawing. Subsurface movement of water is not included and only heat flow in the vertical direction is considered, thus solving an effective 1-D problem and neglecting lateral heat flow between neighbouring cells. This is justified for grid cell sizes considerably larger than the extent of the vertical modelling domain (cf. Westermann et al., 2013).

The model is forced by operational gridded $(1 \times 1 \mathrm{~km})$ air temperature (Lussana et al., 2018; Tveito et al., 2000) and snow-depth (Engeset et al., 2004; Saloranta, 2012). Snow cover data is based on the seNorge snow model (www. senorge.no) that uses gridded observations of daily temperature and precipitation as its input forcing, and simulates, among others, snow water equivalent (SWE), snow depth (SD), and the snow bulk density ( $\rho$ ) (Saloranta, 2012). The 
gridded air temperature for our site is mainly driven by the nearby Skibotn and Rihpojavri weather stations which were validated against our local measurements (see Sect. 3.2). The gridded precipitation for our site is mainly driven by observed precipitation at Skibotn weather station. Since we have no observations of snow cover and owing to the large spatiotemporal variability of snow conditions in our alpine study area, the snow simulations from the seNorge model provide probably the best estimate of the spatial average $1 \times 1 \mathrm{~km}$ snow conditions for our site (cf., Saloranta, 2012). A grid cell covering Polvartinden and similar in elevation (665 $\mathrm{m}$ a.s.1.) as the failure zone was selected. In addition, a grid cell covering the valley floor was selected for validation against our observations. The model parameters for the lower boundary condition and for ground properties were chosen as in Westermann et al. (2013). The surface geology was based on the major surface sediment classification by the Norwegian Geological Survey (NGU, 2010; Thoresen, 1990). For our study sites and the selected grid cells, the sediment stratigraphy was classified as till and coarse colluvium (class 11 according to the sediment map by NGU, 2010) and followed default settings in CG2 with volumetric fractions of the soil constituents and soil type for each layer as given in Westermann et al. (2013). An interval of snow thermal conductivity $\left(k_{\text {snow }}\right)$ was regarded as parameter uncertainty by Westermann et al. (2013), and was used as a confining range for the true conditions as a low $\left(\mathrm{LC}, k_{\text {snow }}=0.3 \mathrm{~W} \mathrm{~m}^{-1} \mathrm{~K}^{-1}\right)$ and a high $\left(\mathrm{HC}, k_{\text {snow }}=0.5 \mathrm{~W} \mathrm{~m}^{-1} \mathrm{~K}^{-1}\right)$ conductivity scenario run of CG2. For validation, one year of daily SST data from the CG2-model was compared with observed SSTdata from our valley and mountain sites. To study long-term changes in ground temperatures and to avoid dominance of near-surface high-frequency temperature variations we selected $10 \mathrm{~m}$ depth as an appropriate depth. For more details on the CG2 model, please refer to Westermann et al. (2013).

\section{Subsurface temperature field}

We employed a transient three-dimensional heat conduction model to get insights into the general pattern of the present subsurface temperature field of Polvartinden. The applied model is discussed in detail in Noetzli et al. (2007a, b) and Noetzli and Gruber (2009) and is basically a finite element model including Fourier's law and phase change via an apparent heat capacity (cf., Mottaghy and Rath, 2006). Where possible, the model was fed with local datasets. The geometry for the simulation was based on a $10 \mathrm{~m}$ digital terrain model for the surface topography of the entire mountain and a rectangular box of $1000 \mathrm{~m}$ height for the subsurface mass. Values defining the subsurface properties (heat capacity, thermal conductivity, porosity; cf. Table 1) were obtained from sites nearby (cf. Lilleøren et al., 2012). Especially for porosity, these values can vary significantly and have quite an influence on the thermal regime. However, due to the similar geological setting and proximity of our site to the sites
Table 1. Values for subsurface properties as used in the stationary three-dimensional transient heat conduction modelling.

\begin{tabular}{ll}
\hline Subsurface property & Value (value range) \\
\hline Heat capacity & $850 \mathrm{~J} \mathrm{~kg}^{-1} \mathrm{~K}^{-1}$ \\
Thermal conductivity & $2-2.5 \mathrm{~W} \mathrm{~m}^{-1} \mathrm{~K}^{-1}$ \\
Density & $2800-2900 \mathrm{~kg} \mathrm{~m}^{-3}$ \\
Water content & $0.2-1 \%$ \\
\hline
\end{tabular}

described in Lilleøren et al. (2012), we assume these values to be fairly representative for our study location. The geothermal heat flux as the lower boundary condition was set to $60 \mathrm{~mW} \mathrm{~m}^{-2}$ (Slagstad et al., 2009). The upper boundary condition was set as a fixed temperature with annual mean values from the distributed MARST. Distributed MARST was calculated based on the aspect dependency of MARST. For this, the fit curve from the first two years of data (October 2009-November 2010, cf. Sect. 4.3) was calculated. MARST changes in the steeper parts of the mountain were assumed to have roughly followed changes in MAAT. The regional LIA glacier maximum is suggested to have occurred about 1900-1910 (e.g. Ballantyne, 1990; Bakke et al., 2005). Therefore, the time-dependent simulation was started with a steady state temperature field for the MARST in 1900, and we assume a linear MAAT increase of $0.55^{\circ} \mathrm{C}$ until the end of the simulation (Lilleøren et al., 2012), i.e. the year of the rock fall event. Our results are only valid for areas that are assumed not to be influenced by a snow cover, i.e. the steep rock-faces of Polvartinden.

\section{Lapse rates}

To study the surface offset and local influences on air temperature lapse rates for our RST locations, we studied the inter-annual variability from 2009-2013 in monthly mean lapse rates. In the absence of local air temperature measurements at higher elevation (similar to the rock wall loggers), the monthly lapse rates were calculated based on the nearest mountain weather station located at Rihpojavri (502 m a.s.l., Fig. 1a) and our local air temperature measurement site in Signaldalen valley (65 $\mathrm{m}$ a.s.1.).

\section{Results}

\subsection{Geomechanical characteristics}

Based on the laser scanning results, the volume of the rock avalanche was estimated to be approximately $500000 \mathrm{~m}^{3}$. These results confirm earlier estimates suggested during the emergency response work initiated directly after the event NGI (2008). The depth to the failure surface was found to range from $40 \mathrm{~m}$ at the back of the failure zone to $0 \mathrm{~m}$ at its toe, with the failure zone being a complex wedge (Fig. 4). 


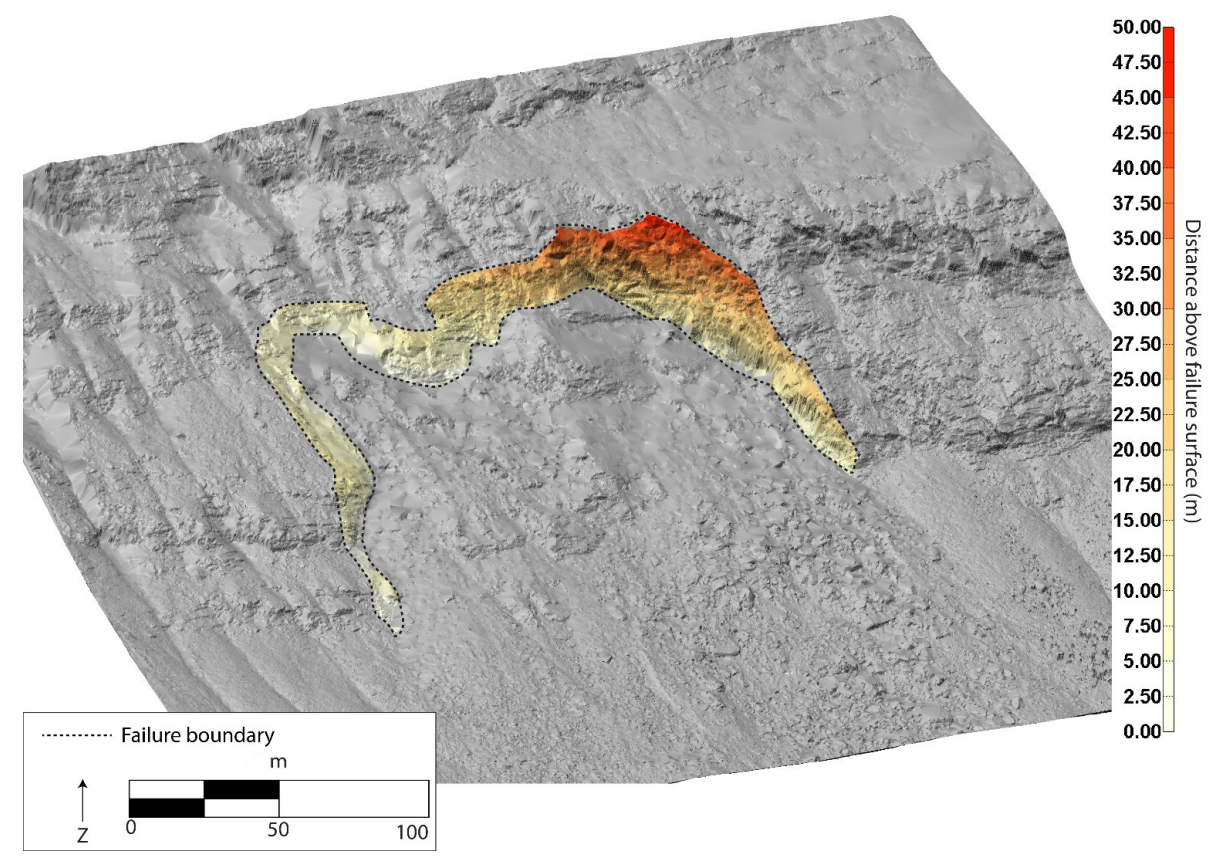

Figure 4. The failure zone of the Signaldalen rock avalanche (outlined with black stippled line) is a complex wedge much deeper to the plane of failure at its back than at the front. The colours indicate the distance in metres to the plane of failure.

Understanding the main mechanism behind the failure involves a kinematic evaluation of the failure scarp. The extraction of the orientation of the basal failure surface and the orientation of the natural slope ("Pre-Failure Surface") are determined directly through measurements using the laser scanning data. Due to the hazardous rock slope, direct measurements from the failure scarp could not be obtainable. The basal failure plane has been identified from the terrestrial laser scanning data and from interpretation of the GigaPan photography (cf. Sect. 3.1). Evaluation of the basal sliding plane showed that it is dipping perpendicular to the rock slope at an average angle of $40^{\circ}$, which is less than the intact rock slope. Based on an approximate friction angle of $30^{\circ}$, the kinematic setting of the rock slope meets the requirements of a sliding failure posing a potential rockfall hazard (see e.g. Hasler et al., 2012; Goodman, 1995).

The surficial change of the exposed rock mass between 2011 and 2013 is mapped through the comparison of laser scanning data collected at different points in time. The maximum size of blocks released between 2011 and 2013 ranges from 1 to $10 \mathrm{~m}^{3}$. In summary, the repeated laser scanning measurements between 2009, 2011, and 2013 showed little to no rockfall activity, both within the 2008 failure zone and in the adjacent rock slopes.

\subsection{Measured mean annual ground surface temperatures}

Measured RST and SST data series for the four-year measurement period were smoothed with a 365-day running

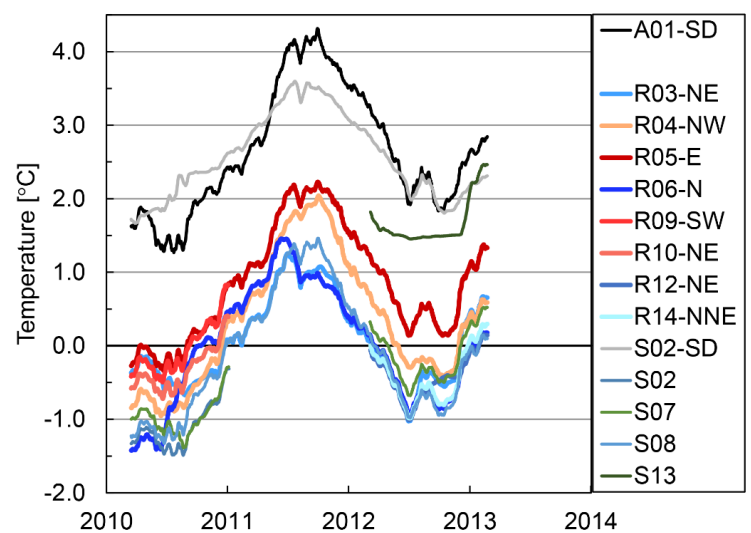

Figure 5. Mean annual rock and soil surface temperatures (all except A01-SD) and air temperature (A01-SD) during the period September 2009 to August 2013 shown as simple moving 365-days average for all sites. To ensure that the temperature variability was not shifted in time, the mean values were centred (an equal number of days on either side of the mean value). A01-SD is air temperature in Signaldalen (SD), R03 to R14 are the rock face loggers, and S02 to $\mathrm{S} 13$ are the soil temperature loggers.

mean filter (Fig. 5). There is a slightly higher variability for MAAT than for MARST and MASST (at ca. $10 \mathrm{~cm}$ depth), but the overall correlation is high. MARST and MASST, measured during 2009-2013, were between -1.4 and $+2.2^{\circ} \mathrm{C}$, with the highest temperatures recorded between April 2011 and March 2012 (Logger R05-E). For the vertical rock face sites, the lowest MARST was recorded at 

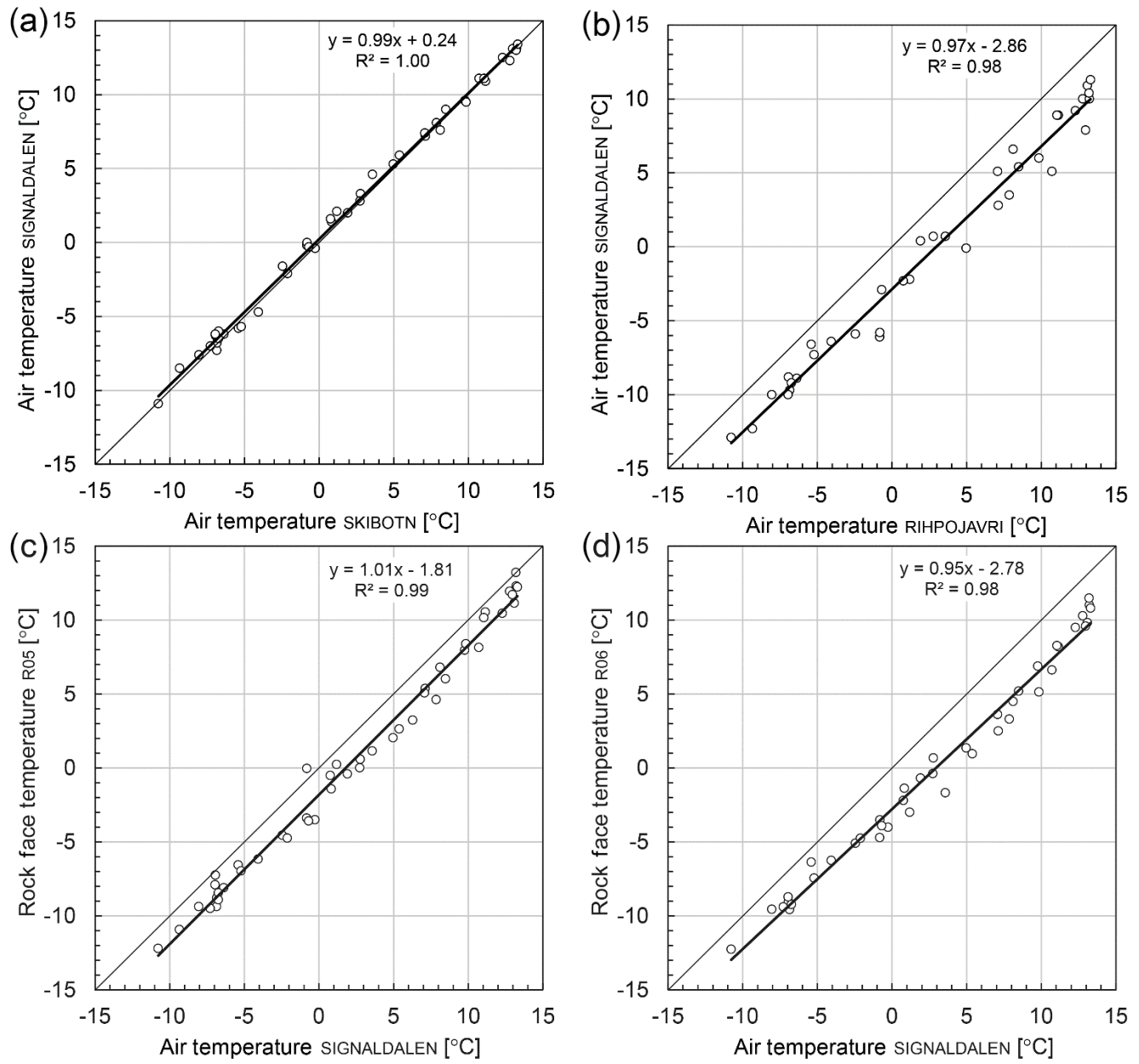

Figure 6. Scatter diagrams showing relations between monthly mean temperature for the main air temperature and rock face temperature series, including linear regression lines. (a) Relation between air temperature in Signaldalen and at meteorological station at Skibotn; (b) relation between air temperature in Signaldalen and air temperature measured at Rihpojavri weather station ( $25 \mathrm{~km}$ from Signaldalen); (c) and (d) relation between rock face temperature logger sites R05 and R06, respectively, and air temperature in Signaldalen.

the north facing site in a 365-day period between September 2009 and September 2010 (Logger R06-N).

The large inter-annual variability found in our temperature measurement series is in congruence with general climate conditions in Troms and is confirmed by measurements in nearby mountain slopes (Farbrot et al., 2013). For the monitoring period 2009-2013, average, minimum and maximum MAAT at the nearby Skibotn meteorological station $(27 \mathrm{~km}$ to the north-north-east from Signaldalen) were $0.0,1.2$ below and $1.5^{\circ} \mathrm{C}$ above the MAAT for the normal period of 1981-2010, respectively.

During 2010 and 2011 some of the sites were clearly influenced by a snow cover (cf. Table 2). Based on an analysis of wind direction, wind speed and total snow accumulation at nearby weather stations (among others Skibotn), we assume this difference in snow cover to be caused by inter-annual differences in prevailing wind direction and preferential snow deposition.
We found a very high correlation between our air temperature measurements in the valley bottom (2009-2013) and air temperature data covering the same period from the nearest two meteorological stations at Skibotn $\left(R^{2}=0.99\right.$; Fig. 6a) and Rihpojavri $\left(R^{2}=0.97\right.$; Fig. $\left.6 \mathrm{~b}\right)$. Furthermore, we found a very high correlation between our local air temperature measurements in the Signaldalen valley floor and the rock wall loggers R05 $\left(R^{2}=0.99\right.$; Fig. 6c $)$ and R06 $\left(R^{2}=0.98\right.$; Fig. 6d). The temperature series from loggers R05 and R06 were chosen because they were the least influenced by snow and they were also the "warmest" and "coldest" loggers, respectively, in the four-year measurement period. Temperatures at logger site $\mathrm{R} 05$ are about $1.3^{\circ} \mathrm{C}$ higher than at the north facing series at logger site R06. This good correlation allowed using the meteorological data from Skibotn for modelling of the long-term evolution of MARST at R05 and R06 for evaluating the potential permafrost distribution near the original failure zone on Polvartinden and recent RST changes 
Table 2. Rock wall and soil temperature loggers installed in Polvartinden and Signaldalen. Snow cover $=$ estimated winter snow cover based on a simple evaluation of day to day temperature variability and standard deviation compared to reference logger R05, divided into three categories: (I) snow cover mostly absent, (II) snow cover over short periods, (III) snow cover over longer periods.

\begin{tabular}{lrrl}
\hline Site & Elevation (ma.s.1.) & Aspect $\left(^{\circ}\right)$ & Snow cover \\
\hline A01-SD & 65 & - & - \\
R03-NE & 640 & 30 & III \\
R04-NW & 657 & 290 & III \\
R05-E & 630 & 90 & I \\
R06-N & 632 & 10 & I-II \\
R09-SW & 646 & 208 & I \\
R10-NE & 598 & 40 & I \\
R12-NE & 668 & 45 & II-III \\
R14-NNE & 608 & 35 & II \\
S02-SD & 64 & - & III \\
S02 & 664 & - & I-II \\
S07 & 626 & - & II \\
S08 & 648 & - & I-II \\
S11 & 540 & - & II \\
S13 & 643 & - & III \\
\hline
\end{tabular}

by coupling our in situ surface temperature data with regional and large-scale climate data.

\subsection{Modelled mean annual ground temperatures}

To be able to link our short temperature rock wall series to the larger regional climate development, we compare it to synthetic temperature time series based on the regressions presented in Fig. 6 and the CG2 simulations. The CG2 model results are representative for our soil temperature sites in the valley floor and for flatter areas at ca. $665 \mathrm{~m}$ a.s.l. (which is roughly the altitude of the failure zone), where snow accumulates and where our soil temperature loggers were installed.

A one-year comparison of observed daily SST at sites with an established soil and snow cover and the modelled SST from the CG2 model is shown in Fig. 7. As seen in Fig. 7a the SST observed in the valley floor is in good agreement $\left(R^{2}=0.86\right.$ to 0.88$)$ with the CG2 model results for a grid cell with approximately the same elevation as the valley floor. The Signaldalen valley is dominated by mountain birch forest and is characterized by an open forest layer with heather and lichen species dominating the forest floor layer. This type of forest causes snow to accumulate and insulates the ground against strong cooling (cf. Isaksen et al., 2008; Farbrot et al., 2013), an effect which can be seen in our CG2 model results. For the SST sites close to the release area (Fig. 7b) there is a somewhat weaker correlation $\left(R^{2}=0.69\right.$ to 0.82$)$ between observed and modelled data. The MASST are about 1 to $1.5^{\circ} \mathrm{C}$ lower than in the $\mathrm{CG} 2$ model for the corresponding grid cell with similar elevation. The warm bias of the simulations during winter is mainly explained by the different
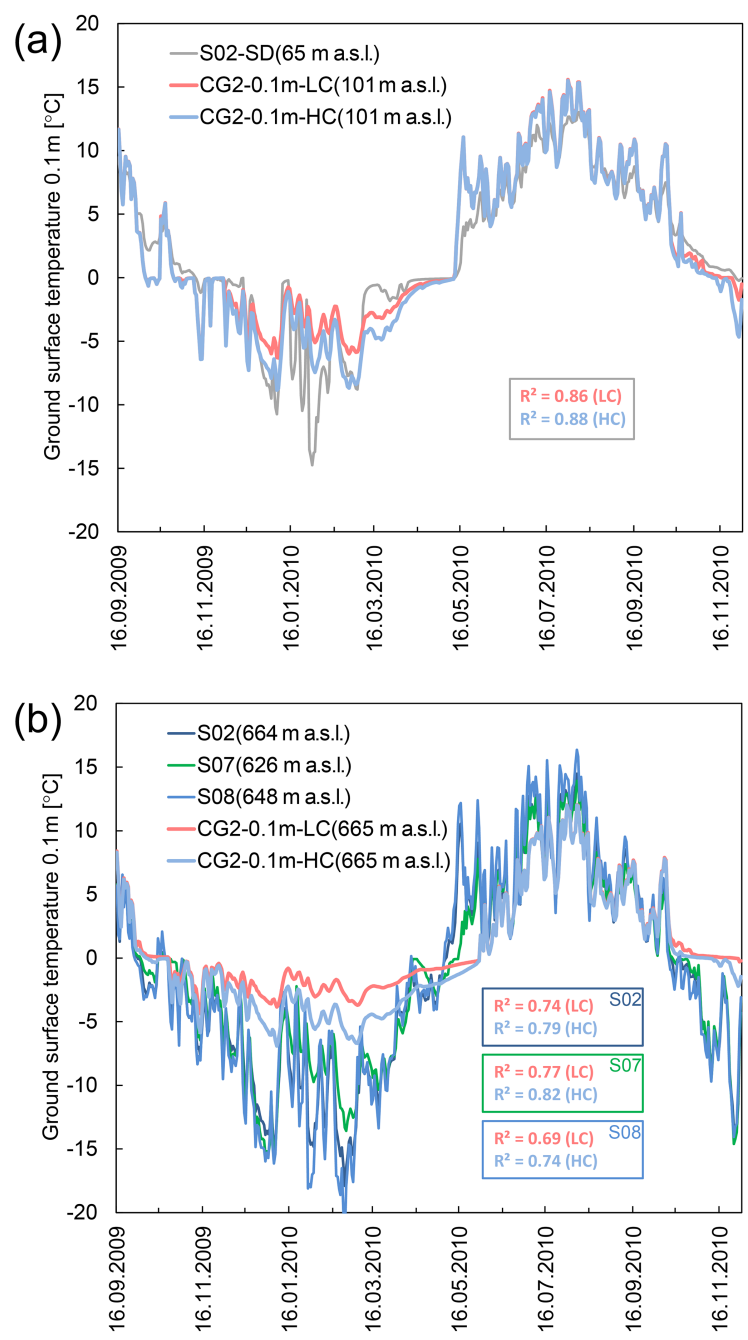

Figure 7. One year of observed soil surface temperatures (SST) at sites with an established soil and snow cover compared with the modelled SST from the transient permafrost model CryoGrid2 (CG2) for high (HC) and low (LC) thermal conductivity of the snow: (a) time series of SST at site S02 - placed next to the air temperature measurement location in the valley floor - compared to the modelled CG2 series for the actual grid cell; (b) SST series for the soil sites close to the release area (S02, S07 and S08) compared to the corresponding grid cell with similar elevation as the release area (i.e. $665 \mathrm{~m}$ a.s.1.).

snow conditions assumed in the model: while our observational sites close to the release area are affected by considerably strong snow cover variations induced by wind drift, the snow model used as input in the CG2-model generally overestimates snow depths in high mountain areas (cf. Saloranta, 2012). This is also in line with results of an equilibrium permafrost model used by Gisnås et al. (2013) who found a better agreement between the CG2-model and validation data when the snow depth in the snow model data was reduced by $30 \%$ for areas above the tree line. During summer, on the 
other hand, our observed SST in the mountains are well reproduced by the CG2 simulations.

The coupling of our coldest in situ RST data from R06 with the climate data from Skibotn since 1958 (cf. Fig. 6) suggests that the highest MARST on record was $1.1^{\circ} \mathrm{C}$ and occurred in the 12-month period between March 2007 and February 2008, i.e. ending four months before the Signaldalen rock avalanche detached (Fig. 8a). A comparison with the CG2 model data run at $10 \mathrm{~m}$ depth for the same period suggests a gradual warming and degradation of the permafrost and supports our synthetic series with the warmest period occurring just a few months prior to the failure. Figure $8 \mathrm{~b}$ shows the recent 10 -year period for the synthetic series and the four-year series of the in situ MARST data for the lowest (R06) and the highest (R05) rock wall temperatures, covering the range of the measured rock wall temperatures. The figure also shows the two CG2 model runs. According to Westermann et al. (2013) the thermal conductivity of the snow is the largest source of uncertainty in CG2, thus a low (LC) and a high conductivity (HC) scenario run of CG2 are used for the last 10 years as a confining range for the true conditions. Note that the synthetic series are slightly warmer than the series for R06 during the first two years. The deviation is likely due to a thin snow cover that partly covered the rock face or outcrop, particularly during the second winter of the monitoring campaign.

Since 1958, the CG2 results clearly indicate a ground warming at $10 \mathrm{~m}$ depth. Coincidentally, the period April 2011 to March 2012 was as warm as the previous record from the early 1990s. On the other hand, our measurements took place during the coldest period since 1988. Our measurement period covers, in other words, most of the temperature regime that can be expected in this region within a multi-decadal perspective. The depth of the fracture zone varies between 20 to $40 \mathrm{~m}$ (Fig. 4). Temperature penetration from the surface to such depths typically takes between one $(20 \mathrm{~m})$ to two years $(40 \mathrm{~m})$ (e.g. Gruber et al., 2004b). Therefore, there is a good temporal link between the maximum ground temperature at $20-40 \mathrm{~m}$ depth (through at least the last $50-60$ years) and the actual timing of the rock avalanche release.

The general pattern of the transient 3-D-temperature field in the mountain is illustrated with a 2-D transect from south to north (see Sect. 5). The curvature of the isotherms inside the mountain stems from the topography and is more pronounced the steeper the topography is (Noetzli et al., 2007a). Since the difference in MARST is only on the order of $1.5^{\circ} \mathrm{C}$, the isotherms are a little inclined towards the colder mountain flank. However, the main temperature change in the subsurface is experienced with a change in altitude (unlike in, e.g. steep peaks in the Alps, where the main temperature change is experienced for positions between mountain flanks with different temperature). Based on this schematic sketch of the subsurface temperatures, the permafrost body underlies all of the steeper part of the mountain and is several hundred me-
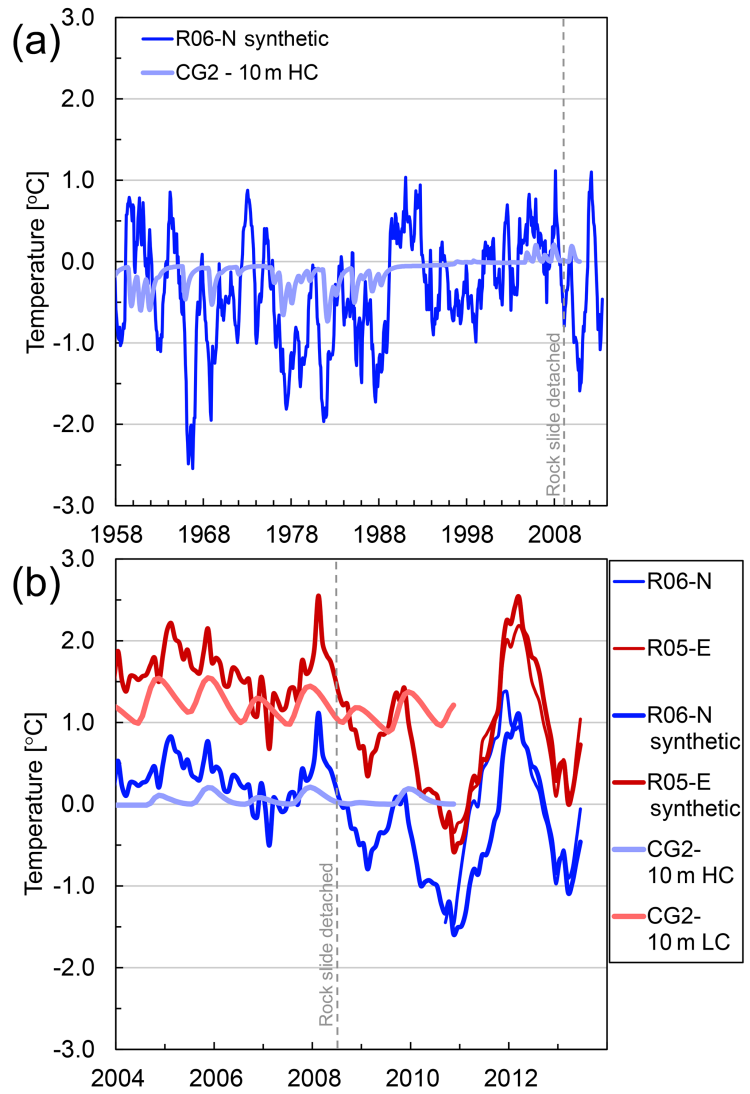

Figure 8. (a) Synthetic temperature series since 1958 of the coldest rock wall site (R06) based on the regression presented in Fig. 6. Also shown is the transient permafrost model CryoGrid2 (CG2) run that calculates ground temperatures at $10 \mathrm{~m}$ depth according to conductive heat transfer in the soil and in the snowpack (Westermann et al., 2013). The CG2 model results are representative for areas at approximately $665 \mathrm{~m}$ a.s.l. with slope gradients allowing for snow accumulation. The grey dotted line shows when the Signaldalen rock avalanche detached; (b) The recent 10-year period for the synthetic series overlaid on the respective in situ RST data for the lowest (R06, blue lines) and highest (R05, red lines) rock wall temperatures. Also shown are the CG2 model data runs at $10 \mathrm{~m}$ depth for high (HC) and low (LC) thermal conductivity values of the snow.

tres thick at some places. In the area of the rock fall starting zone more shallow permafrost is simulated.

\subsection{Local lapse rate}

As shown in Fig. 6 our regression analysis shows a high correlation between the nearest mountain weather station located at Rihpojavri (502 m a.s.l., Fig. 1) and our local air temperature measurement site in Signaldalen valley $(65 \mathrm{~m}$ a.s.l., Fig. 3b). Figure 9 reveals an annual median lapse rate of $6.1^{\circ} \mathrm{C} \mathrm{km}^{-1}$, but with substantial seasonal and inter-annual variability. Lapse rates are smallest $\left(4-6^{\circ} \mathrm{C} \mathrm{km}^{-1}\right)$ in latesummer to early autumn, and largest $\left(7-10^{\circ} \mathrm{C} \mathrm{km}^{-1}\right)$ in spring. We see the strongest gradients in spring (May). 


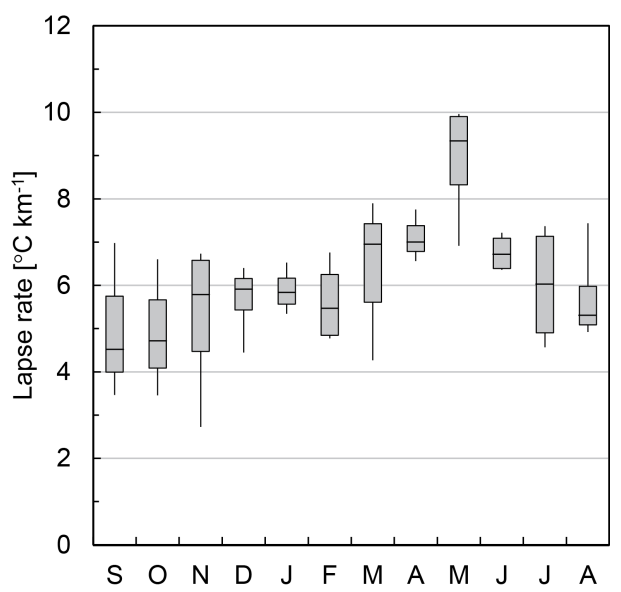

Figure 9. Inter-annual variability between 2009-2013 of the monthly-mean lapse rates based on air temperature data from Rihpojavri (502 $\mathrm{m}$ a.s.1.) and Signaldalen (65 $\mathrm{m}$ a.s.1.). Boxes show the interquartile range of the month's lapse rate, horizontal lines inside the boxes show the median values, and the whiskers show the full range of the data.

The monthly temperature difference $(\Delta T)$ between calculated air temperature and measured rock face temperatures are shown in Fig. 10. For the sites R03, R04, and R12, periods during which the loggers obviously had been covered by snow (cf. Table 2) were omitted. Monthly values were calculated in the same way as used for the lapse-rate calculations (cf. Sect. 3.4, Fig. 9). The results in Fig. 10 show a clear aspect dependency with a slightly lower $\Delta T$ in northern exposition as opposed to slopes exposed to the south. The figure also shows the year to year variations on the order of \pm 0.5 to $1.0^{\circ} \mathrm{C}$. There is a clear seasonal dependency, with $\Delta T$ near $0^{\circ} \mathrm{C}$ or even negative during autumn and early winter, and largest $\Delta T\left(1.5\right.$ to $\left.5^{\circ} \mathrm{C}\right)$ in late spring and early summer.

Figure 11a shows the annual temperature difference $(\Delta T)$ between calculated air temperature and measured rock face temperatures and aspect dependency as derived from the data. The $\Delta T$ for logger R06, which is the logger facing most towards north $\left(10^{\circ}\right)$, is $+0.6^{\circ} \mathrm{C}$ compared to air temperature, while the two loggers facing most towards south (R05, $90^{\circ}$ and R09, 208 ${ }^{\circ}$ ) show both a $\Delta T$ of $+1.7^{\circ} \mathrm{C}$. We, thus find an aspect difference between north and south facing loggers of $1.1^{\circ} \mathrm{C}$. Figure $11 \mathrm{~b}$ shows the subsurface temperature field as modelled with the stationary three-dimensional transient heat conduction model based on rock wall temperature data from 2009-2011. The figure shows a slice transecting Polvartinden mountain from south (left) to north (right).

\section{Discussion}

A uniform and/or constant theoretical lapse rate is often set to $6.5^{\circ} \mathrm{C} \mathrm{km}^{-1}$ (e.g. International Organization for Standardization, 1975). However, the theoretical adiabatic lapse
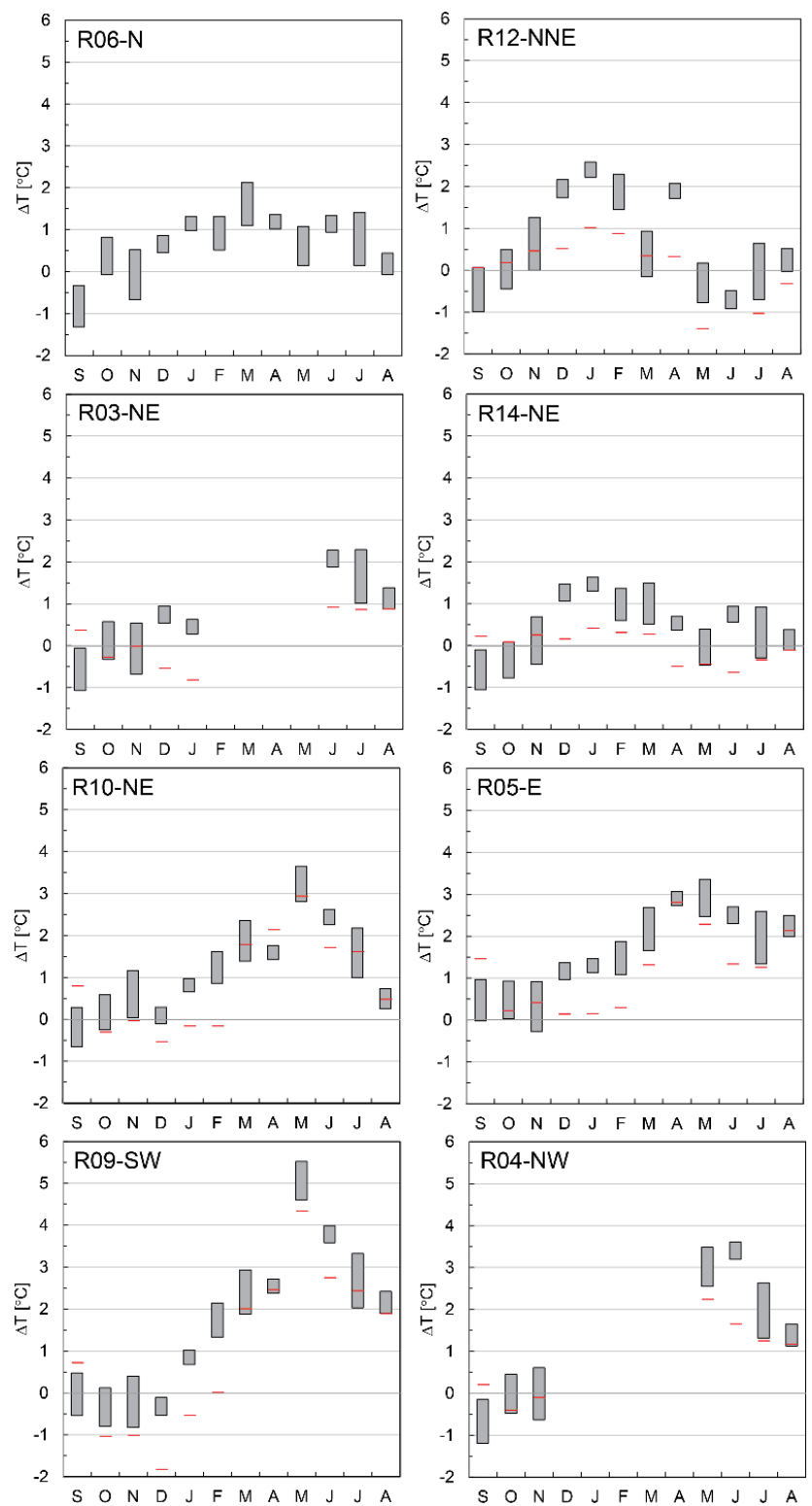

Figure 10. Monthly temperature difference $(\Delta T)$ between calculated air temperature and measured rock face temperatures from 2009-2013. Calculated air temperature is based on air temperature from Signaldalen (65 ma.s.1.) and the lapse rates shown in Fig. 9. Boxes show the interquartile range of $\Delta T$. The red horizontal lines show the monthly-mean temperature difference between the respective loggers and the north facing (i.e. the coldest) logger R06. Loggers R03, R04, and R12 were snow covered during winter and data from snow-influenced months were removed. For R09 and R10 only data for 2009-2011 exist, for R12 and R14 only for 2011-2013.

rate can vary considerably (from 3 to $9{ }^{\circ} \mathrm{C} \mathrm{km}^{-1}$ for surface conditions at mid-latitudes) due to its dependency on pressure and temperature (Minder et al., 2010). In valley bottoms, temperature inversions and cold air pooling can affect lapse rates (e.g. Rolland, 2003), and channelled flow over moun- 

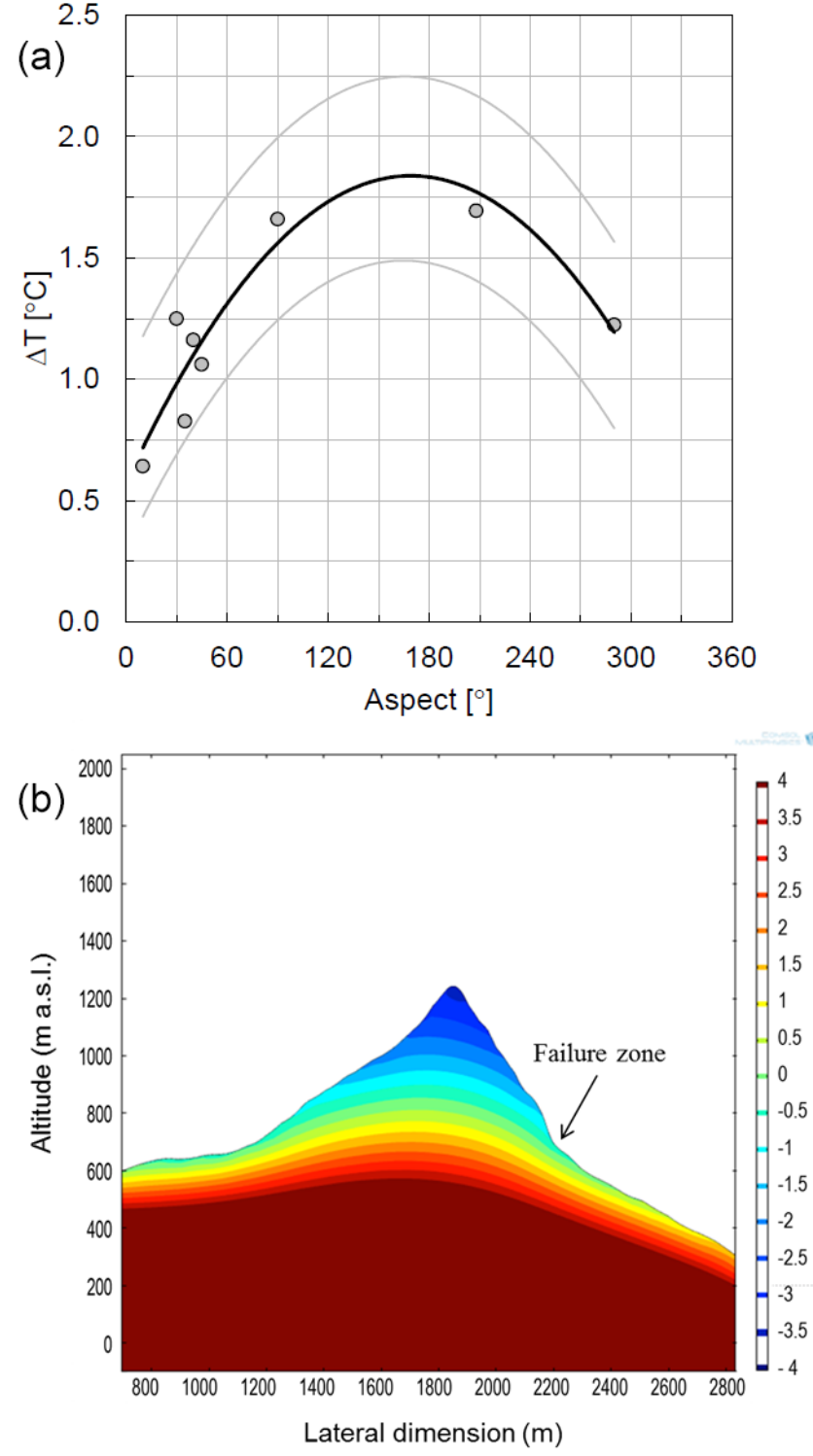

Figure 11. (a) Annual temperature difference $(\Delta T)$ between calculated air temperature and measured rock face temperatures and aspect dependency as derived from the rock wall temperature data. The points represent mean values and the black line is the best polynomial fit to the data $\left(R^{2}=0.84\right)$. The grey lines show the polynomial fit to the interquartile range of $\Delta T$; (b) 3-D transient heat modelling of the subsurface temperature field based on values identified in (a). Figure shows a slice transecting the mountain from south (left) to north (right).

tain passes can result in large local temperature anomalies (e.g. Steenburgh et al., 1997).

Our study suggests that the high lapse rate values we find in Signaldalen in spring are caused by the fact that the snow cover is normally depleted in the valley bottom in late spring, while the higher areas and the northerly exposed, moderately steep mountain slopes still exhibit an extensive snow cover.
These results are in accordance with international literature (e.g. Minder et al., 2010) and are likely applicable to other mountainous areas in northern Norway. Other studies have also shown that seasonal cycles in lapse rates have similar amplitudes to those found in our study, but that the phasing of the seasonality varies (Bolstad et al., 1998; Rolland, 2003; Tang and Fang, 2006; Blandford et al., 2008; Gardner et al., 2009). They also highlight the importance of local air temperature measurements in experimental observational networks to reduce uncertainty. Our results clearly support these findings.

Our measured MARST and MASST values from the period 2009-2013 indicate warm and marginal permafrost at all temperature logger sites facing north-northeast, i.e. in the same aspect as the failure zone. Our results yield an estimated mean lower limit of permafrost at around 600$650 \mathrm{~m}$ a.s.l.; this value is in agreement with earlier estimates in the inner fjord and valley areas of Troms (Farbrot et al., 2013; Gisnås et al., 2017) and coincides with the upper limit of the failure zone. Since all rock wall loggers are installed on small cliffs (rather than in vertical, large rock walls) the snow close and/or at the top of these cliffs can attenuate normal winter cooling and, thus affect the results during the winter months. This is visible in Fig. 10, where some of the northeast facing loggers exhibit clearly higher winter temperatures than what would be expected when compared with air temperature. The influence of the snow cover on the rock thermal regime has been studied in steep rock walls (Haberkorn et al., 2015a, b; Hasler et al., 2011; Magnin et al., 2015). The highly variable spatial and temporal distribution of the snow cover strongly influences the ground thermal regime of steep rock faces (Haberkorn et al., 2015a, b; Magnin et al., 2015). Haberkorn et al. (2015a) found that snow depths exceeding $0.2 \mathrm{~m}$ were enough to have an insulating effect on steep, bare bedrock. Such amounts are likely to accumulate in steep, high rock walls with a certain degree of surface roughness. As snow reduces ground heat loss in winter, it has an overall warming effect on both north and south facing rock walls despite the fact that it provides protection from solar radiation in early summer (Haberkorn et al., 2017). However, in moderately inclined $\left(45-70^{\circ}\right)$ sun-exposed rock walls, Hasler et al. (2011) suggest a reduction of MARST of up to $3{ }^{\circ} \mathrm{C}$ compared to estimates in near-vertical, compact rock due to snow persistence during the months with most intense radiation. In our study some of the soil logger sites feature moss or thin vegetation (like the mountainside otherwise), which also affects the temperature. Together, the loggers (including the soil loggers) reflect the variation of the snow and surface conditions present around the Signaldalen rock avalanche site.

The long-term development in the annual mean temperatures from the instrumental period (the late 19th-century) in northern Norway can be split into four periods: a cold period in the beginning, a period referred to as "early 20th century warming" culminating in the 1930s, a period of 


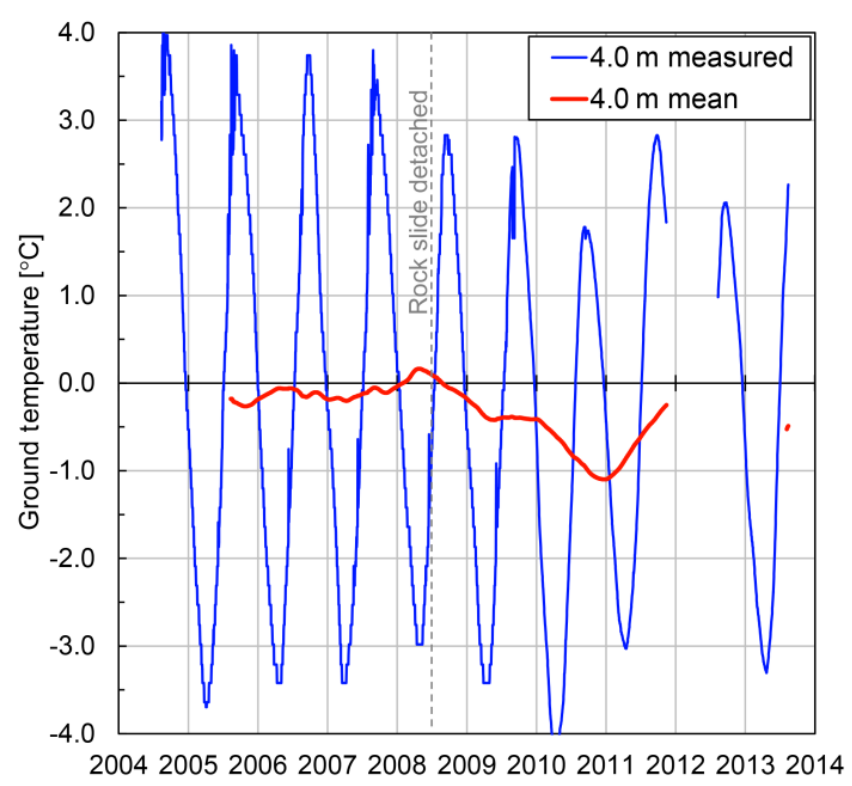

Figure 12. Ground temperature time-series at $4 \mathrm{~m}$ depth from a nearby permafrost borehole (Guolasjávri (Gu-B-1), 786 ma.s.1.; more details can be found in Farbrot et al., 2013). The blue line shows the measured daily values and the red line shows a simple moving 365-days average, i.e. the unweighted mean of the previous 365 days. The grey dotted line indicates the detachment date of the Signaldalen rock avalanche.

cooling from the 1930s to the 1960 s, and finally the "recent warming" from the 1960s to present (Hanssen-Bauer et al., 2015). Regional climate data since 1958 from Skibotn weather station suggest a general warming of the greater Signaldalen area. This is in agreement with the general atmospheric warming (Hanssen-Bauer et al., 2015) and observed permafrost temperature rise (Isaksen et al., 2007), and the long-term permafrost degradation (Farbrot et al., 2013) in northern-Norway, with an observed peak during the period 2007-2009 (Christiansen et al., 2010; Romanovsky et al., 2016). The CG2 model results suggest (not shown) an increase of the lower permafrost limit for snow covered sites from ca. $600 \mathrm{~m}$ a.s.l. in the 1960 s to about $800 \mathrm{~m}$ a.s.l. between 2000-2010 (Sebastian Westermann, personal communication, 2015). Our modelled data (Fig. 8) and observed ground temperature data from the nearby Guolasjávri permafrost borehole (Fig. 12, see location in Fig. 1) suggest that the highest mean near surface temperatures on record occurred in the period between March 2007 and February 2008, thus ending only a few months before the Signaldalen rock avalanche detached.

According to a study by Fischer et al. (2012) on potential triggering factors at 56 historical rock avalanche and rockfall events in the Alps, it seems to be the marginal permafrost zones where most of the recent changes concerning ice content and hydrology have taken place; parameters that are seen as having an important influence on slope stability (see also
Allen and Huggel, 2013, Deline et al., 2011, and Fischer et al., 2013). In laboratory studies, Davies et al. (2001) demonstrated that the shear strength of an ice-bonded rock discontinuity significantly reduces with warming and that the minimum shear stress is reached between ca. -0.5 and $0{ }^{\circ} \mathrm{C}$. Krautblatter et al. (2013) showed that fracture ice influences stability down to a depth of approximately $20 \mathrm{~m}$. Below this depth, the overburden pressure of the rock mass becomes too high. According to their study, intact rock bridges and rockrock contacts exert additional control on rock stability. While permafrost increases the uniaxial and tensile strength of such rock bridges and rock-rock contacts, warming of permafrost decreases these strengths and could thus trigger rock slope failures. In degrading permafrost, rock-mechanical properties may control early stages of destabilization and become more important for higher normal stress, i.e. higher magnitudes of rock slope failure. Ice-mechanical properties outbalance the importance of rock-mechanical components after the deformation accelerates and are more relevant for smaller magnitudes (Krautblatter et al., 2013). In early summer, the combined effect of hydrostatic and cryostatic pressure can cause a peak in shear force exceeding high frozen shear resistance (Dräbing et al., 2014).

Analysing temperature conditions prior to 144 past rockfall events in the Swiss Alps and the French Mont Blanc massive, Lüthi et al. (2015) recently showed that small to medium-sized rockfalls (with volumes up to $100000 \mathrm{~m}^{3}$ ) mainly occurred during short-term periods of unusually high temperatures, whereas larger high-elevation rock slope failures occur all year-round. Hasler et al. (2011) showed that local warming of cold permafrost may be induced by advection and the related erosion of cleft ice and that permafrost degradation through thermal advection by running water can rapidly lead to the development of deep thaw corridors along fracture zones and potentially destabilise much larger volumes of rock than through thermal conduction on similar timescales. Dräbing et al. (2016) found that the rock mechanical regime also was snow-controlled in permafrost rock slopes at Steintaelli in the Swiss Alps. They found that during snow-free periods, high-frequency thermal expansion and contraction occurred. Rock temperature locally dropped to $-10^{\circ} \mathrm{C}$, resulting in thermal contraction of the rock slopes. Snow cover insulation maintained temperatures in the frostcracking window and favoured ice segregation. Such repetitive occurrence destabilises the rock slope and can potentially lead to failure (Dräbing et al., 2016).

A recent synopsis of MARST at 34 locations within the PERMOS network in Switzerland (Noetzli et al., 2016) shows that MARST are generally higher than MAAT. In south-exposed near-vertical locations this difference amounts to up to $10^{\circ} \mathrm{C}$. In north-exposed locations, MARST is only slightly higher than MAAT (Noetzli et al., 2016), including steep alpine rock walls at the Matterhorn and the Jungfraujoch in Switzerland (Hasler et al., 2011). Similar values were also measured at the Aiguille du Midi in France 
(by Magnin et al., 2015). In Scandinavia, the amount of studies using direct observations to explore the influence of solar radiation on near surface temperatures in different aspects of steep mountain walls is limited so far. In Jotunheimen, southern Norway, north facing rock wall surfaces were on average less than $1^{\circ} \mathrm{C}$ warmer than the surrounding air temperature, while MARST in more radiation exposed rock walls was up to $4{ }^{\circ} \mathrm{C}$ higher than MAAT (Hipp et al., 2014). Generally, the influence of direct solar radiation is less pronounced at high latitudes than in mid-latitude mountains. Our results indicate an altitudinal difference of roughly $200-250 \mathrm{~m}$ between northerly and southerly aspect (cf. Fig. 11b), as compared to $1000-1500 \mathrm{~m}$ (or up to $8-10^{\circ} \mathrm{C}$ ) for some sites in the Swiss Alps (Noetzli et al., 2016). Due to our small sample size, these results should be seen as tentative estimates. Also, the potential effect of the midnight sun has not been looked at. In addition, it has to be noted that we lack loggers exposed directly to the south. Based on the shape of the polynomial fit curve (Fig. 11a), and on what is known from other studies (e.g. Gruber et al., 2004b; Noetzli and Gruber, 2009; Magnin et al., 2015; Noetzli et al., 2016), the difference between northerly and southerly aspects is probably 0.2 to $0.4^{\circ} \mathrm{C}$ higher than indicated by our measurements. This would yield an absolute difference between "warmest" and "coldest" aspects of approximately $1.3-1.5^{\circ} \mathrm{C}$, which is still considerably lower than for mid-latitude mountain ranges and about $1.5^{\circ} \mathrm{C}$ lower than reported by Hipp et al. (2014) for a location in southern Norway, thus supporting strongly decreasing aspect dependency with increasing latitude. Smaller differences in MARST between north and south facing rock walls eventually result in less pronounced 3-D effects of the subsurface temperature field as illustrated with the modelling results of the subsurface temperature field (Fig. 11b). For alpine peaks with a triangular geometry, isotherms can be nearly vertical in the uppermost part of mountain peaks in the European Alps (cf. Noetzli et al., 2007b), and temperatures change mainly with the position between north and south facing slopes. In our results, isotherms are only minorly inclined, and the main change in subsurface temperatures is experienced with changing altitude and not changing exposition.

\section{Conclusions}

In June 2008, a rock avalanche detached in the northeast facing slope of Polvartinden, a high-alpine mountain in Signaldalen, northern Norway. The volume calculation based on terrestrial laser scanning data showed that the depth to the actual failure surface was found to range from $40 \mathrm{~m}$ at the back to $0 \mathrm{~m}$ at the toe. Repeated laser scanning between 2009 and 2013 showed little to no activity in both the 2008 failure zone and the adjacent rock slopes.
Analyses based on four-year rock and soil surface temperature series suggest warm and marginal permafrost at several of the investigated sites in Signaldalen, and yield an estimated mean lower limit of permafrost at around 600$650 \mathrm{~m}$ a.s.l., an altitude which coincides with the upper limit of the failure zone. Regional climate data since 1958 and nearby permafrost borehole data suggest a general warming and that the highest mean near surface temperatures on record occurred some months before the Signaldalen rock avalanche detached. These findings are supported by model results of the transient permafrost model CG2. Considering that temperature penetration to, e.g. 15-20 m depth in frozen rock typically takes one year it is likely that changing rock and ice-temperatures due to the general warming and in response to the extreme warm previous year have played an important role in the detaching of the Signaldalen rock avalanche.

Our results give also new insights into aspect dependency of mountain permafrost in northern Scandinavia, a subject that has been little explored so far. We found an absolute difference in ground surface temperatures of approximately 1.3 to $1.5^{\circ} \mathrm{C}$ between southern and northern exposed slopes, values considerably lower than reported from studies in midlatitude mountain ranges.

Data availability. The meteorological data analysed in this paper are available on https://frost.met.no/index.html. All other temperature data, as well as the lidar data, are available upon request to the first author.

Competing interests. The authors declare that they have no conflict of interest.

Special issue statement. This article is part of the special issue "The evolution of permafrost in mountain regions". It is not associated with a conference.

Acknowledgements. The work of Regula Frauenfelder and Matthew J. Lato was funded by the Norwegian Research Council (through its base funding to NGI) and the work of Ketil Isaksen was funded through the Norwegian Meteorological Institute, all this funding is gratefully acknowledged. Michael Krautblatter and three anonymous reviewers are gratefully acknowledged for their thorough and helpful reviews which greatly improved the final paper. We also express our thanks to editor Christian Hauck who contributed with important comments and suggestions to further improve the manuscript. We are indebted to Leif Skogli (Signaldalen) who let us install loggers on his property and helped with the logistics during the laser scanning campaigns. In addition, we would like to thank Steinar Engsted (former employee at Storfjord municipality) for his interest in our work. Kjetil Brattlien (NGI), Gunnar Kristensen (NVE), and Gunilla Kaiser are thanked for letting us use their photographs. Herman Farbrot, Gunilla Kaiser, 
Kristin Sæterdal Myhra, and Helge Smebye are acknowledged for their help in the field. Last but certainly not least, Sebastian Westermann (UiO) deserves a great thanks for running his CG2 model for us and letting us use the according results.

Edited by: Christian Hauck

Reviewed by: Michael Krautblatter and three anonymous referees

\section{References}

Allen, S. and Huggel, C.: Extremely warm temperatures as a potential cause of recent high mountain rockfall, Global Planet. Change, 107, 59-69, 2013.

Allen, S., Cox, S. C., and Owens, I. F.: Rock avalanches and other landslides in the central Southern Alps of New Zealand: a regional study considering possible climate change impacts, Landslides, 8, 33-48, https://doi.org/10.1007/s10346-010-0222z, 2011.

Andresen, A.: Caledonian Terranes of Northern Norway and their characteristics: Trabajos de Geologia, Univ. de Oviedo, 17, 103$117,1988$.

Arenson, L. and Jakob, M.: Permafrost-Related Geohazards and Infrastructure Construction in Mountainous Environments, Oxford Research Encyclopedia of Natural Hazard Science, Oxford University Press, USA, https://doi.org/10.1093/acrefore/9780199389407.013.292, 2017.

Arenson, L. and Springman, S.: Triaxial constant stress and constant strain rate test on ice-rich permafrost samples, Can. Geotech. J., 42, 412-430, 2005.

Arenson, L., Springman, S., and Sego, D. C.: The rheology of frozen soils, Appl. Rheol., 17, 1-14, 2007.

Auer, I., Böhm, R., Jurkovic, A., Lipa, W., Orlik, A., Potzmann, R., Schöner, W., Ungersböck, M., Matulla, C., Briffa, K., Jones, P., Efthymiadis, D., Brunetti, M., Nanni, T., Maugeri, M., Mercalli, L., Mestre, O., Moisseline, J. M., Begert, M., MüllerWestermeier, G., Kveton, V., Bochnicek, O., Stastny, P., Lapin, M., Szalai, S., Szentimrey, T., Cegnar, T., Dolinar, M., GajicCapka, M., Zaninovic, K., Majstorovic, Z., and Nieplova, E.: HISTALP - Historical instrumental climatological surface time series of the Greater Alpine Region, Int. J. Climatol., 27, 17-46, 2007.

Ballantyne, C. K.: The Holocene glacial history of Lyngshalvøya, northern Norway - chronology and climatic implications, Boreas, 19, 93-117, 1990.

Ballantyne, C. K.: Paraglacial geomorphology, Quaternary Sci. Rev., 21, 1935-2017, 2002.

Bakke, J., Dahl, S. O., Paasche, O., Lovlie, R., and Nesje, A.: Glacier fluctuations, equilibrium-line altitudes and palaeoclimate in Lyngen, northern Norway, during the Lateglacial and Holocene, Holocene, 15, 518-540, 2005.

Barla, G., Dutto, F., and Mortara, G.: Brenva Glacier rock avalanche of 18 January 1997 on the Mont Blanc range, northwest Italy, Landslide News, 13, 2-5, 2000.

Bergh, S. G., Eig, K., Kløvjan, O. S., Henningsen, T., Olesen, O., and Hansen, J.: The Lofoten-Vesterålen continental margin: a multiphase Mesozoic-Palaeogene rifted shelf by offshore- onshore brittle fault-fracture analysis, Norw. J. Geol., 87, 29-58, 2007.

Blandford, T. R., Humes, K. S., Harshburger, B. J., Moore, B. C., Walden, V. P., and Ye, H.: Seasonal and Synoptic Variations in Near-Surface Air Temperature Lapse Rates in a Mountainous Basin, J. Appl. Meteorol. Clim., 47, 249-261, https://doi.org/10.1175/2007JAMC1565.1, 2008.

Blikra, L. H. and Christiansen, H. H.: A field-based model of permafrost-controlled rockslide deformation in northern Norway, Geomorphology, 208, 34-49, https://doi.org/10.1016/j.geomorph.2013.11.014, 2014.

Blikra, L. H., Longva, O., Braathen, A., Anda, E., Dehls, J. F., and Stalsberg, K.: Rock slope failures in Norwegian fjord areas; examples, spatial distribution and temporal pattern, Landslides From Massive Rock Slope Failure, Springer Dordrecht, the Netherlands, 475-496, 2006.

Blikra, L. H., Christensen, H. H., Kristensen, L., and Lovisolo M.: Characterization, Geometry, Temporal Evolution and Controlling Mechanisms of the Jettan Rock-Slide, Northern Norway, Engineering Geology for Society and Territory, vol. 2, Springer International Publishing, 273-278, 2015.

Böhm, R., Auer, I., Brunetti, M., Maugeri, M., Nanni, T., and Schöner, W.: Regional temperature variability in the European Alps: 1760-1998 from homogenized instrumental time series, Int. J. Climatol., 21, 1779-1801, 2001.

Bolstad, P. V., Swift, L., Collins, F., and Régnière, J.: Measured and predicted air temperatures at basin to regional scales in the southern Appalachian mountains, Agr. Forest Meteorol., 91, 161-176, https://doi.org/10.1016/S0168-1923(98)00076-8, 1998.

Christiansen, H. H., Etzelmüller, B., Isaksen, K., Juliussen, H., Farbrot, H., Humlum, O., Johansson, M., Ingeman-Nielsen, T., Kristensen, L., Hjort, J., Holmlund, P., Sannel, A. B. K., Sigsgaard, C., Åkerman, H. J., Foged, N., Blikra, L. H., Pernosky, M. A., and Ødegård, R.: The Thermal State of Permafrost in the Nordic area during the IPY 2007-2009, Permafrost Periglac., 21, 156181, https://doi.org/10.1002/ppp.687, 2010.

Cola, G.: The large landslide of the south-east face of Thurwieser peak (Thurwieser-Spitze) $3658 \mathrm{~m}$ (Upper Valtellina, Italy), Terra Glacialis, 8, 38-45, 2005.

Crosta, G. B., Chen, H., and Lee, C. F.: Replay of the 1987 Val Pola Landslide, Italian Alps, Geomorphology, 60, 127-146, 2004.

Davies, M. C. R., Hamza, O., and Harris, C.: The effect of rise in mean annual temperature on the stability of rock slopes containing ice-filled discontinuities, Permafrost Periglac., 12, 137-144. https://doi.org/10.1002/ppp.378, 2001.

Dehls, J. F., Olesen, O., Olsen, L., and Blikra, L. H.: Neotectonic faulting in northern Norway, the Stuoragurra and Nordmannvikdalen postglacial faults, Quaternary Sci. Rev., 19, 14471460, 2000.

Deline, P., Alberto, W., Broccolato, M., Hungr, O., Noetzli, J., Ravanel, L., and Tamburini, A.: The December 2008 Crammont rock avalanche, Mont Blanc massif area, Italy, Nat. Hazards Earth Syst. Sci., 11, 3307-3318, https://doi.org/10.5194/nhess11-3307-2011, 2011.

Dräbing, D., Krautblatter, M., and Dikau, R.: Interaction of thermal and mechanical processes in steep permafrost rock walls: A conceptual approach, Geomorphology, 226, 226-235, dio:10.1016/j.geomorph.2014.08.009, 2014. 
Dräbing, D., Haberkorn, A., Krautblatter, M., Kenner, R., and Phillips, M.: Thermal and Mechanical Responses Resulting From Spatial and Temporal Snow Cover Variability in Permafrost Rock Slopes, Steintaelli, Swiss Alps, Permafrost Periglac., 28, 140-157, https://doi.org/10.1002/ppp.1921, 2016.

Dwivedi, R. D., Singh, P. K., Singh, T. N., and Singh, D. P.: Compressive strength and tensile strength of rocks at sub-zero temperature, Indian J. Eng. Mater. S., 5, 43-48, 1998.

Dwivedi, R. D., Soni, A. K., Goel, R. K., and Dube, A. K.: Fracture toughness of rocks under sub-zero temperature conditions, Int. J. Rock Mech. Min., 37, 1267-1275, 2000.

Engeset, R., Tveito, O. E., Alfnes, E., Mengistu, Z., Udnæs, H.-C., Isaksen, K., and Førland, E. J.: Snow map system for Norway, 23rd Nordic Hydrological Conference, Tallin, Estonia, NHP Report, 48, 112-121, 2004.

Etzelmüller, B., Berthling, I., and Sollid, J. L.: Aspects and concepts on the geomorphological significance of Holocene permafrost in southern Norway, Geomorphology, 52, 87-104, https://doi.org/10.1016/S0169-555X(02)00250-7, 2003.

Evans, S. G. and Clague, J. J.: Recent climatic change and catastrophic geomorphic processes in mountain environments, Geomorphology, 10, 107-128, 1994.

Farbrot, H., Isaksen, K., and Etzelmüller, B.: Present and past distribution of mountain permafrost in the Gaissane Mountains, northern Norway, Proceedings of the Ninth International Conference on Permafrost, edited by: Kane, D. L. and Hinkel, K. M., Institute of Northern Engineering, University of Alaska Fairbanks, Fairbanks, Alaska, USA, 427-432, 2008.

Farbrot, H., Hipp, T., Etzelmüller, B., Isaksen, K., Ødegård, R. S., Schuler, T. V., and Humlum, O.: Air and ground temperature variations observed along elevation and continentality gradients in Southern Norway, Permafrost Periglac., 22, 343-360, https://doi.org/10.1002/ppp.733, 2011.

Farbrot, H., Isaksen, K., Etzelmüller, B., and Gisnås, K.: Ground Thermal Regime and Permafrost Distribution under a Changing Climate in Northern Norway, Permafrost Periglac., 24, 20-38, https://doi.org/10.1002/ppp.1763, 2013.

Fischer, L., Purves, R. S., Huggel, C., Noetzli, J., and Haeberli, W.: On the influence of topographic, geological and cryospheric factors on rock avalanches and rockfalls in highmountain areas, Nat. Hazards Earth Syst. Sci., 12, 241-254, https://doi.org/10.5194/nhess-12-241-2012, 2012.

Fischer, L., Huggel, C., Kääb, A., and Haeberli, W.: Slope failures and erosion rates on a glacierized high-mountain face under climatic changes, Earth Surf. Proc. Land., 38, 836-846, 2013.

Fossen, H., Pedersen, R. B., Bergh, S., and Andresen, A.: En fjellkjede blir til, Oppbygningen av Kaledonidene; ca. 500-450 millioner år, in: Landet blir til, Norges Geologi, chap. 6, edited by: Ramberg, I. B., Bryhni, I., Nøttvedt, A., and Rangsnes, K., Norwegian Geological Society, 178-229, 2007 (in Norwegian).

Gardner, A. S., Sharp, M. J., Koerner, R. M., Labine, C., Boon, S., Marshall, S. J., Burgess, D. O., and Lewis, D.: Near-Surface Temperature Lapse Rates over Arctic Glaciers and Their Implications for Temperature Downscaling, J. Climate, 22, 4281-4298, https://doi.org/10.1175/2009JCLI2845.1, 2009.

Geertsema, M., Clague, J. J, Schwab, J. W., and Evans, S. G.: An overview of recent large catastrophic landslides in northern British Columbia, Canada, Eng. Geol., 83, 120-143, 2006.
Gisnås, K., Etzelmüller, B., Farbrot, H., Schuler, T., and Westermann, S.: CryoGRID 1.0: Permafrost distribution in Norway estimated by a spatial numerical model, Permafrost Periglac., 24, 2-19, 2013.

Gisnås, K., Etzelmüller, B., Lussana, C., Hjort, J., Sannell, A. B. K., Isaksen, K., Westermann, S., Kuhry, P., Christiansen, H. H.: Permafrost map for Norway, Sweden and Finland, Permafrost Periglac., 28, 359-378, 2017.

Gobiet, A., Kotlarski, S., Beniston, M., Heinrich, G., Rajczak, J., and Stoffel, M.: 21st century climate changes in the European Alps - A review, Sci. Total Environ., 493, 1138-1151, 2014.

Goodman, R. E.: Block theory and its application, Geotechnique, 45, 383-423, 1995.

Gruber, S. and Haeberli, W.: Permafrost in steep bedrock slopes and its temperature-related destabilization following climate change, J. Geophys. Res., 112, F02S18, https://doi.org/10.1029/2006JF000547, 2007.

Gruber, S., Hoelzle, M., and Haeberli, W.: Rock wall temperatures in the Alps - modelling their topographic distribution and regional differences, Permafrost Periglac., 15, 299-307, 2004a.

Gruber, S., Hoelzle, M., and Haeberli, W.: Permafrost thaw and destabilization of Alpine rock walls in the hot summer of 2003, Geophys. Res. Lett., 31, L13504, https://doi.org/10.1029/2004GL020051, 2004b.

Gruber, S., Peter, M., Hoelzle, M., Woodhatch, I., and Haeberli, W.: Surface temperatures in steep Alpine rock faces - a strategy for regional-scale measurement and modelling, Proceedings of the 8th International Conference on Permafrost 2003, Zurich, Switzerland, 325-330, 2003.

Günzel, F.: Shear strength of ice-filled rock joints, Proceedings of the 9th International Conference on Permafrost, Fairbanks, Alaska, International Permafrost Association, 581-586, 2008.

Haberkorn, A., Hoelzle, M., Phillips, M., and Kenner, R.: Snow as driving factor of rock surface temperatures in steep rough rock walls, Cold Reg. Sci. Technol., 118, 64-75, https://doi.org/10.1016/j.coldregions.2015.06.013, 2015a.

Haberkorn, A., Phillips, M., Kenner, R., Rhyner, H., Bavay, M., Galos, S. P., and Hoelzle, M.: Thermal Regime of Rock and its Relation to Snow Cover in Steep Alpine Rock Walls: Gemsstock, Central Swiss Alps, Geogr. Ann. A, 97, 579-597, https://doi.org/10.1111/geoa.12101, 2015b.

Haberkorn, A., Wever, N., Hoelzle, M., Phillips, M., Kenner, R., Bavay, M., and Lehning, M.: Distributed snow and rock temperature modelling in steep rock walls using Alpine3D, The Cryosphere, 11, 585-607, https://doi.org/10.5194/tc-11585-2017, 2017.

Haeberli, W., Huggel, C., Kääb, A., Polkvoj, A., Zotikov I., and Osokin, N.: The Kolka-Karmadon rock/ice slide of 20 September 2002: An extraordinary event of historical dimensions in North Ossetia, Russian Caucasus, J. Glaciol., 50, 533-546, 2004.

Haeberli, W., Noetzli, J., Arenson, L., Delaloye, R., Gärtner-Roer, I., Gruber, S., Isaksen, K., Kneisel, C., Krautblatter, M., and Phillips, M.: Mountain permafrost: development and challenges of a young research field, J. Glaciol., 56, 1043-1058, 2010.

Hansen, J. A.: Onshore-offshore tectonic relations on the Lofoten and Vesterålen Margin: Mesozoic to early Cenozoic structural evolution and morphological implications, University of Troms $\varnothing$, Norway, Faculty of Science, Dept. of Geology, 229, 2009. 
Hanssen-Bauer, I., Førland, E. J., Haddeland, I., Hisdal, H., Mayer, S., Nesje, A., Nilsen, J. E. Ø., Sandven, S., Sandø, A. B., Sorteberg, A., and Ådlandsvik, B. (Eds.): Klima i Norge $2100-$ Kunnskapsgrunnlag for klimatilpasning oppdatert i 2015, NCCS report no. 2/2015, https://klimaservicesenter.no/, 2015 (in Norwegian).

Harris, C., Arenson, L. U., Christiansen, H. H., Etzelmüller, B., Frauenfelder, R., Gruber, S., Haeberli, W., Hauck, C., Hölzle, M., Humlum, O., Isaksen, K., Kääb, A., Kern-Lütschg, M. A., Lehning, M., Matsuoka, N., Murton, J. B., Nötzli, J., Phillips, M., Ross, N., Seppälä, M., Springman, S. M., and Vonder Mühll, D.: Permafrost and climate in Europe: Monitoring and modelling thermal, geomorphological and geotechnical responses, EarthSci. Rev., 92, 117-171, 2009.

Hasler, A., Gruber, S., and Haeberli, W.: Temperature variability and offset in steep alpine rock and ice faces, The Cryosphere, 5, 977-988, https://doi.org/10.5194/tc-5-977-2011, 2011.

Hasler, A., Gruber, S., and Beutel, J.: Kinematics of steep bedrock permafrost, J. Geophys. Res., 117, F01016, https://doi.org/10.1029/2011JF001981, 2012.

Heggem, E. S. F., Juliussen, H., and Etzelmüller, B.: Mountain permafrost in Central-Eastern Norway, Norsk Geogr. Tidsskr., 59, 94-108, 2005.

Hermanns, R. L., Oppikofer, T., Anda, E., Blikra, L. H., Böhme, M., Bunkholt, H., Crosta, G. B., Dahle, H., Devoli, G., Fischer, L., Jaboyedoff, M., Loew, S., Sætre, S., and Yugsi Molina, F. $\mathrm{X}$.: Recommended hazard and risk classification system for large unstable rock slopes in Norway, NGU rapport 2012.029, Norwegian Geological Survey, Trondheim, Norway, 2012.

Hermanns, R. L., Blikra, L. H., Anda, E., Saintot, A., Dahle, H., Oppikofer, T., Fischer, L., Bunkholt, H., Böhme, M., Dehls, J. F., Lauknes, T. R., Redfield, T. F., Osmundsen, P. T., and Eiken, T.: Systematic Mapping of Large Unstable Rock Slopes in Norway, Landslide Science and Practice, Springer, Berlin Heidelberg, https://doi.org/10.1007/978-3-642-31325-7_3, 2013.

Hermanns, R. L., Oppikofer, T., Böhme, M., Dehls, J. F., Yugsi Molina, F. X., and Penna, I. M.: Rock slope instabilities in Norway: First systematic hazard and risk classification of 22 unstable rock slopes from northern, western and southern Norway, Landslides and Engineered Slopes, Experience, Theory and Practice, Associazione Geotecnica Italiana, Rome, Italy, ISBN 978-1-13802988-0, 2016.

Hermanns, R. L, Schleier, M., Böhme, M., Blikra, L. H., Gosse, J., Ivy-Ochs, S., and Hilger, P.: Rock-Avalanche Activity in W and S Norway Peaks After the Retreat of the Scandinavian Ice Sheet, in: Advancing Culture of Living with Landslides, Mikoš M., Vilímek V., Yin Y., and Sassa K., Springer International Publishing AG, 331-338, https://doi.org/10.1007/978-3-319-534831_39, 2017.

Hipp, T. F., Etzelmüller, B., and Westermann, S.: Permafrost in Alpine Rock Faces from Jotunheimen and Hurrungane, Southern Norway, Permafrost Periglac., 25, 1-13, https://doi.org/10.1002/ppp.1799, 2014.

Huggel, C., Salzmann, N., Allen, S., Caplan-Auerbach, J., Fischer, L., Haeberli, W., Larsen, C., Schneider, D., and Wessels, R.: Recent and future warm extreme events and high-mountain slope stability, Philos. T. R. Soc. S.-A, 368, 2435-2459, 2010.
Hungr, O., Leroueil, S., and Picarelli, L.: The Varnes classification of landslide types, an update, Landslides, 11, 167-194, https://doi.org/10.1007/s10346-013-0436-y, 2014.

Inada, Y. and Yokota, K.: Some studies of low-temperature rock strength, Int. J. Rock Mech. Min., 21, 145-153, 1984.

International Organization for Standardization (ISO): Standard Atmosphere, ISO 2533, 1975.

Isaksen, K., Sollid, J. L., Holmlund, P., and Harris, C.: Recent warming of mountain permafrost in Svalbard and Scandinavia, J. Geophys. Res., 112, F02S04, https://doi.org/10.1029/2006JF000522, 2007.

Isaksen, K., Farbrot, H., Blikra, L. H. Johansen, B., and Sollid, J. L.: Five-year ground surface temperature measurements in Finnmark, northern Norway, Proceedings of the Ninth International Conference on Permafrost, edited by: Kane, D. L. and Hinkel, K. M., Institute of Northern Engineering, University of Alaska Fairbanks, Fairbanks, Alaska, USA, 789-794, 2008.

Isaksen, K., Ødegård, R. S., Etzelmüller, B., Hilbich, C., Hauck, C., Farbrot, H., Eiken, T., Hygen, H. O., and Hipp, T. F.: Degrading mountain permafrost in southern Norway: Spatial and temporal variability of mean ground temperatures, 1999-2009, Permafrost Periglac., 22, 361-377, https://doi.org/10.1002/ppp.728, 2011.

Jia, H., Leith, K., and Krautblatter, M.: Quantifying rock fatigue and decreasing compressive and tensile strength after repeated freeze-thaw cycles, Permafrost Periglac., 26, 368-377, 2016.

Jia, H., Xiang, W., and Krautblatter, M.: Path-Dependent FrostWedging Experiments in Fractured, Low-Permeability Granite, Permafrost Periglac., 28, 698-709, 2017.

Jin, H., Li, S., Cheng, G., Wang, S., and Li, X.: Permafrost and climatic change in China, Global Planet. Change, 26, 387-404, 2000.

Juliussen, H., Christiansen, H. H., Strand, G. S., Iversen, S., Midttømme, K., and Rønning, J. S.: NORPERM, the Norwegian Permafrost Database - a TSP NORWAY IPY legacy, Earth Syst. Sci. Data, 2, 235-246, https://doi.org/10.5194/essd-2-235-2010, 2010.

King, L.: Zonation and Ecology of High Mountain Permafrost in Scandinavia, Geogr. Ann. A, 68, 131-139, https://doi.org/10.2307/521452, 1986.

Krautblatter, M., Funk, D., and Günzel, F. K.: Why permafrost rocks become unstable: a rock-ice-mechanical model in time and space, Earth Surf. Proc. Land., 38, 876-887, https://doi.org/10.1002/esp.3374, 2013.

Lato, M., Diederichs, M., and Hutchinson, D. J.: Bias correction for static LiDAR scanning of rock outcrops for structural characterization, Rock Mech. Rock Eng., 43, 615-628, 2010.

Lato, M., Hutchinson, D. J., Gauthier, D., Edwards, T., and Ondercin, M.: Comparison of ALS, TLS and terrestrial photogrammetry for mapping differential slope change in mountainous terrain, Can. Geotech. J., 52, 129-140, https://doi.org/10.1139/cgj2014-0051, 2014.

Lato, M., Diederichs, M. S., Hutchinson, D. J., and Harrap, R.: Evaluating roadside rockmasses for rockfall hazards using LiDAR data: optimizing data collection and processing protocols, Nat. Hazards, 60, 831-864, 2012.

Lilleøren, K., Etzelmüller, B., Gisnås, K., and Humlum, O.: The relative age of mountain permafrost-estimation of Holocene permafrost limits in Norway, Global Planet. Change, 92-93, 209223, 2012. 
Lüthi, R., Gruber, S., and Ravanel, L.: Modelling transient ground surface temperatures of past rockfall events: towards a better understanding of failure mechanisms in changing periglacial environments, Geogr. Ann. A, 97, 753-767, https://doi.org/10.1111/geoa.12114, 2015.

Lussana, C., Tveito, O. E., and Uboldi, F.: Three-dimensional spatial interpolation of $2 \mathrm{~m}$ temperature over Norway, Q. J. Roy. Meteorol. Soc., 144, 344-364, https://doi.org/10.1002/qj.3208, 2018.

Magnin, F., Deline, P., Ravanel, L., Noetzli, J., and Pogliotti, P.: Thermal characteristics of permafrost in the steep alpine rock walls of the Aiguille du Midi (Mont Blanc Massif, $3842 \mathrm{~m}$ a.s.1), The Cryosphere, 9, 109-121, https://doi.org/10.5194/tc-9-1092015, 2015.

Marchenko, S. S., Gorbunov, A. P., and Romanovsky, V. E.: Permafrost warming in the Tien Shan mountains, Central Asia, Global Planet. Change, 56, 311-327, 2007.

Mellor, M.: Mechanical properties of rocks at low temperatures, 2nd International Conference on Permafrost, Yakutsk, International Permafrost Association, Postdam, 334-344, 1973.

Minder, J. R., Mote, P. W., and Lundquist, J. D.: Surface temperature lapse rates over complex terrain: Lessons from the Cascade Mountains, J. Geophys. Res., 115, D14122, https://doi.org/10.1029/2009JD013493, 2010.

Mottaghy, D. and Rath, V.: Latent heat effects in subsurface heat transport modelling and their impact on palaeotemperature reconstructions, Geophys. J. Int., 164, 236-245, https://doi.org/10.1111/j.1365-246x.2005.02843.x, 2006.

Myhra, K. S., Westermann, S., and Etzelmüller, B.: Modelled Distribution and Temporal Evolution of Permafrost in Steep Rock Walls Along a Latitudinal Transect in Norway by CryoGrid 2D, Permafrost Periglac., 28, 172-182, https://doi.org/10.1002/ppp.1884, 2015.

Nesje, A.: Brelære, Kristiansand, Høyskoleforlaget AS, Norwegian Academic Press, 2012 (in Norwegian).

NGU: Produktspesifikasjon ND Løsmasser, Norges Geologiske Undersøkelser, 2010 (in Norwegian).

Noetzli, J. and Gruber, S.: Transient thermal effects in Alpine permafrost, The Cryosphere, 3, 85-99, https://doi.org/10.5194/tc-385-2009, 2009.

Noetzli, J., Gruber, S., Kohl, T., Salzmann, N., and Haeberli, W.: Three-dimensional distribution and evolution of permafrost temperatures in idealized high-mountain topography, J. Geophys. Res.-Earth, 112, F02S13, https://doi.org/10.1029/2006JF000545, 2007a.

Noetzli, J., Gruber, S., and Friedel, S.: Modeling transient permafrost temperatures below steep alpine topography, COMSOL User Conference, Grenoble, 139-143, 2007b.

Noetzli, J., Lüthi, R., and Staub, B. (Eds.): PERMOS: Permafrost in Switzerland 2010/2011 to 2013/2014, Glaciological Report (Permafrost) no. 12-15 of the Cryospheric Commission of the Swiss Academy of Sciences, 85 pp., 2016.

Norwegian Meteorological Institute: Archive of historical weather and climate data, https://frost.met.no/index.html, last access: 5 December 2017.

Oppikofer, T., Jaboyedoff, M., and Keusen, H.-R.: Collapse at the eastern Eiger flank in the Swiss Alps, Nat. Geosci., 1, 31-535, 2008.
Ødegård, R. S., Hoelzle, M., Vedel Johansen, K., and Sollid, J. L.: Permafrost mapping and prospecting in southern Norway, Norsk Geogr. Tidsskr., 50, 41-53, https://doi.org/10.1080/00291959608552351, 1996.

Phillips, M., Wolter, A., Lüthi, R., Amann, F., Kenner, R., and Bühler, Y.: Rock slope failure in a recently deglaciated permafrost rock wall at Piz Kesch (Eastern Swiss Alps), February 2014, Earth Surf. Proc. Land., 42, 426-438, https://doi.org/10.1002/esp.3992, 2016.

Ravanel, L. and Deline, P.: Climate influence on rockfalls in high-Alpine steep rockwalls: the north side of the Aiguilles de Chamonix (Mont Blanc massif) since the end of the Little Ice Age, Holocene, 21, 357-365, https://doi.org/10.1177/0959683610374887, 2010.

Roberts, D.: The Scandinavian Caledonides: event chronology, palaeogeographic settings and likely modern analogues, Tectonophysics, 365, 283-299, 2002.

Roberts, D. and Gee, D.: An introduction to the structure of the Scandinavian Caledonides, in: The Caledonide Orogen - Scandinavia and Related Areas, edited by: Gee, D. G. and Sturt, B. A., John Wiley and Sons Ltd., Chichester, 55-68, 1985.

Rolland, C.: Spatial and Seasonal Variations of Air Temperature Lapse Rates in Alpine Regions, J. Climate, 16, 1032-1046, https://doi.org/10.1175/15200442(2003)016<1032:SASVOA>2.0.CO;2, 2003.

Romanovsky, V. E., Smith, S. L., Isaksen, K., Shiklomanov, N. I., Streletskiy, D. A., Kholodov, A. L., Christiansen, H. H., Drozdov, D. S., Malkova, G. V., and Marchenko, S. S.: Terrestrial permafrost, in "State of the Climate in 2015", B. Am. Meteorol. Soc., 97, S149-S152, 2016.

Saloranta, T. M.: Simulating snow maps for Norway: description and statistical evaluation of the seNorge snow model, The Cryosphere, 6, 1323-1337, https://doi.org/10.5194/tc-6-13232012, 2012.

Schleier, M., Hermanns, R. L., Gosse, J. C., Oppikofer, T., and Tønnesen, J. F.: Subaqueous rock-avalanche deposits exposed by post-glacial isostatic rebound, Innfjorddalen, Western Norway, Geomorphology, 289, 117-133, doi.org/10.1016/j.geomorph.2016.08.024, 2017.

Slagstad, T., Balling, N., Elvebakk, H., Midttømme, K., Olesen, O., Olsen, L., and Pascal, C.: Heat-flow measurements in Late Palaeoproterozoic to Permian geological provinces in south and central Norway and a new heat-flow map of Fennoscandia and the Norwegian-Greenland Sea, Tectonophysics, 473, 341-361, 2009.

Steenburgh, W. J., Mass, C. F., and Ferguson, S. A.: The Influence of Terrain-Induced Circulations on Wintertime Temperature and Snow Level in the Washington Cascades, Weather Forecast., 12, 208-227, https://doi.org/10.1175/15200434(1997)012<0208:TIOTIC>2.0.CO;2, 1997.

Stoffel, M. and Huggel, C.: Mass Movements in Periglacial Environments, in International Encyclopedia of Geography: People, the Earth, Environment and Technology, edited by: Richardson, D., Castree, N., Goodchild, M. F., Kobayashi, A., Liu, W., and Marston, R. A., John Wiley and Sons, Ltd, Oxford, last access: 22 June 2017.

Stoffel, M., Tiranti, D., and Huggel, C.: Climate change impacts on mass movements - case studies from the European Alps, Sci. Total Environ., 493, 1255-1266, 2014. 
Sveian, H.: Isen kom - og forsvant, in: Ka dokker mein førr stein!, edited by: Dahl, R. and Sveian, H., Norwegian Geological Survey, 2004 (in Norwegian).

Sveian, H. and Corner, G.: Lyngens isbreer før og nå, in: Ka dokker mein førr stein!, edited by: Dahl, R. and Sveian, H., Norwegian Geological Survey, 2004 (in Norwegian).

Tang, Z. and Fang, J.: Temperature variation along the northern and southern slopes of Mt. Taibai, China, Agr. Forest Meteorol., 139, 200-207, https://doi.org/10.1016/j.agrformet.2006.07.001, 2006.

Thoresen, M.: Kvartærgeologisk kart over Norge, tema jordarter, Norwegian Geological Survey, Trondheim, Norge, 1990 (in Norwegian).

Tveito, O. E., Førland, E. J., Heino, R., Hanssen- Bauer, I., Alexandersson, H., Dahlstrøm, B., Drebs, A., Kern-Hansen, C., Vaarby Laursen, E., and Westman, Y.: Nordic temperature maps, DNMI, Oslo, Report no. 09/00, available at: http://met.no/filestore/09_ 00.pdf, 2000.
Vavrus, S.: The role of terrestrial snow cover in the climate system, Clim. Dynam., 29, 73-88, https://doi.org/10.1007/s00382-0070226-0, 2007.

Vorren, T. O. and Mangerud, J.: Istider kommer og går, chap. 15, in: Landet blir til, Norsk geologisk forening, edited by: Ramberg, I. B., Bryhni, I., Nøttvedt, A., and Rangsnes, K., Trondheim, 478531, 2007 (in Norwegian).

Wang, Q., Fan, X., and Wang, M.: Recent warming amplification over high elevation regions across the globe, Clim. Dynam., 43, 87-101, https://doi.org/10.1007/s00382-013-1889-3, 2014.

Westermann, S., Schuler, T. V., Gisnås, K., and Etzelmüller, B.: Transient thermal modeling of permafrost conditions in Southern Norway, The Cryosphere, 7, 719-739, https://doi.org/10.5194/tc7-719-2013, 2013. 